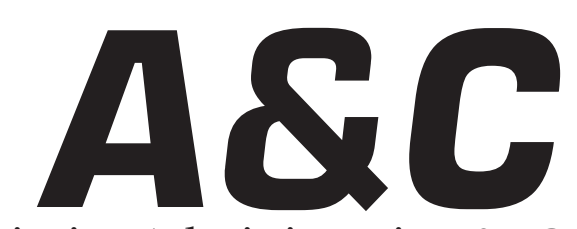

Revista de Direito Administrativo \& Constitucional

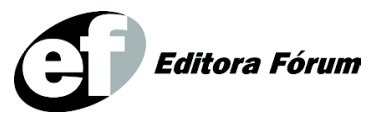

ISSN 1516-3210 


\section{A\&C REVISTA DE DIREITO ADMINISTRATIVO E CONSTITUCIONAL}

IPDA

Instituto Paranaense

de Direito Administrativo

Direção Geral

Romeu Felipe Bacellar Filho

Direção Editorial

Paulo Roberto Ferreira Motta

Direção Executiva

Emerson Gabardo

Conselho de Redação

Edgar Chiuratto Guimarães

Adriana da Costa Ricardo Schier

Célio Heitor Guimarães

\section{Conselho Editorial}

Adilson Abreu Dallari

Alice Gonzáles Borges

Carlos Ari Sundfeld

Carlos Ayres Britto

Carlos Delpiazzo

Cármen Lúcia Antunes Rocha

Celso Antônio Bandeira de Mello

Clèmerson Merlin Clève

Clóvis Beznos

Enrique Silva Cimma

Eros Roberto Grau

Fabrício Motta

Guilhermo Andrés Muñoz (in memoriam)

Jaime Rodríguez-Arana Muñoz

Jorge Luís Salomoni

José Carlos Abraão
José Eduardo Martins Cardoso
José Luís Said
José Mario Serrate Paz
Juan Pablo Cajarville Peruffo
Juarez Freitas
Julio Rodolfo Comadira
Luís Enrique Chase Plate
Lúcia Valle Figueiredo
Manoel de Oliveira Franco Sobrinho
(in memoriam)
Marçal Justen Filho
Marcelo Figueiredo
Márcio Cammarosano
Maria Cristina Cesar de Oliveira

Nelson Figueiredo

Odilon Borges Junior

Pascual Caiella

Paulo Eduardo Garrido Modesto

Paulo Henrique Blasi

Paulo Neves de Carvalho (in memoriam)

Paulo Ricardo Schier

Pedro Paulo de Almeida Dutra

Regina Maria Macedo Nery Ferrari

Rogério Gesta Leal

Rolando Pantoja Bauzá

Sérgio Ferraz

Valmir Pontes Filho

Yara Stropa

Weida Zancaner

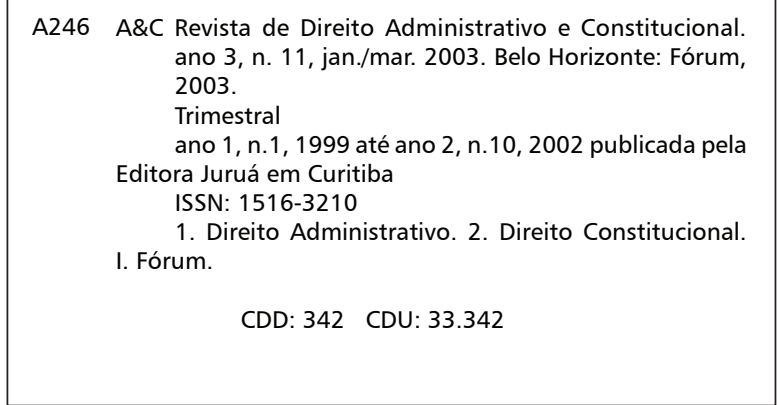

(c) Editora Fórum Ltda. 2006

Todos os direitos reservados. É proibida a reprodução total ou parcial, de qualquer forma ou por qualquer meio eletrônico ou mecânico, inclusive através de processos xerográficos, de fotocópias ou de gravação, sem permissão por escrito do possuidor dos direitos de cópias (Lei $n^{\circ}$ 9.610, de 19.02.1998).

Editora Fórum Ltda

Av. Afonso Pena, 2770 - 15\%16ª andar - Funcionários

CEP 30130-007 - Belo Horizonte/MG - Brasil

Tel.: 08007043737

Internet: www.editoraforum.com.br

e-mail: editoraforum@editoraforum.com.br
Editor responsável: Luís Cláudio Rodrigues Ferreira Projeto gráfico e diagramação: Luis Alberto Pimenta Revisora: Olga M. A. Sousa

Pesquisa jurídica: Fátima Ribeiro - OAB/MG 74868

Bibliotecária: Alessandra Rodrigues da Silva - CRB 2778/

MG 6a Região

Os conceitos e opiniões expressas nos trabalhos assinados são de responsabilidade exclusiva de seus autores.

Impressa no Brasil / Printed in Brazil

Distribuída em todo Território Nacional 


\title{
Contagem dos prazos prescricionais da lei penal para punições disciplinares de servidores públicos: uma paralela reflexão crítica sobre os conceitos de tipicidade e discricionariedade das faltas administrativas para os fins do art. 142, $\S 2^{\circ}$, da Lei ${ }^{\circ} 8.112 / 90$
}

\begin{abstract}
Antonio Carlos Alencar Carvalho
Procurador do Distrito Federal. Advogado em Brasília-DF. Pós-graduando em Direito Público e Advocacia Pública pelo IDP. Procurador-assessor e ex-chefe da Assessoria Especial do Gabinete do Procurador-Geral do Distrito Federal
\end{abstract}

Sumário: - Pressupostos para a incidência da lei penal para contagem dos prazos de prescrição em casos de crimes tipificados como infrações disciplinares - Origem do dispositivo do art. $142, \S^{\circ}$, da Lei $\mathrm{n}^{\circ}$ 8.112/90 e conceito de falta disciplinar que também constitui crime - Crimes comuns à luz da regra do art. $142, \S 2^{\circ}$, da Lei $\mathrm{n}^{\circ} 8.112 / 90$ - Crítica parcial à jurisprudência do Superior Tribunal de Justiça na interpretação do art. 142, §2º, da Lei no 8.112/90, no caso de crimes comuns, e comentários sobre os reflexos do princípio da legalidade na enumeração das faltas disciplinares: a questão da tipicidade e da discricionariedade no direito administrativo disciplinar - Crimes contra a Administração Pública, como infração disciplinar passível de demissão expressamente prevista no estatuto dos servidores públicos federais - Princípio da legalidade na imposição de sanções e a tipicidade de infrações disciplinares - Tendências da tipicidade das faltas sujeitas a penas mais graves no direito administrativo disciplinar: discricionariedade e tipos abertos e fechados de infrações administrativas: o modelo da ordem jurídica federal - Evolução quanto à idéia inicial do direito francês de desnecessidade de previsão legal das infrações disciplinares, senão apenas das sanções aplicáveis: perspectiva corrente no direito brasileiro e estrangeiro - Os limites da discricionariedade administrativa no Estado democrático de Direito: a consagração da tipicidade das faltas sujeitas a sanções mais graves no direito positivo federal brasileiro e na doutrina desde o Estatuto dos Servidores Públicos Federais de 1939 - Responsabilidade administrativa e tipicidade de infrações disciplinares Caráter exaustivo das hipóteses de demissão, cassação de aposentadoria ou disponibilidade na disciplina da Lei no 8.112/90 - Previsão de crimes comuns como faltas disciplinares no estatuto dos servidores públicos como pressuposto para contagem dos prazos prescricionais da lei penal para punição administrativa - Descabimento da contagem dos prazos prescricionais da lei penal para punição de infrações estritamente disciplinares - Desclassificação dos crimes comuns para faltas exclusivamente disciplinares como meio de viabilizar a punição administrativa, mas segundo os prazos ordinários do estatuto do funcionalismo - Interpretação restritiva do art. $142, \S 2^{\circ}$, da Lei $\mathrm{n}^{\circ} 8.112 / 90$ na atual disciplina do direito positivo federal - Estatutos estaduais 
e municipais que capitulam crimes comuns como infrações disciplinares Auxílio-reclusão e prática de crime comum cuja sentença penal condenatória respectiva não determina a perda do cargo público - Pressupostos complementares para contagem dos prazos prescricionais da lei penal para punição administrativa na jurisprudência do Superior Tribunal de Justiça - Acusação da prática de crime como artifício para permitir a punição do servidor público após já estar prescrita a pretensão punitiva da Administração Pública segundo os prazos ordinários do estatuto dos servidores: precedentes do Supremo Tribunal Federal - Conclusões - Referências

Palavras-chave: Administração Pública. Servidor público. Lei no 8.112/90 art. 142. Estatuto disciplinar. Faltas administrativas.

Pressupostos para a incidência da lei penal para contagem dos prazos de prescrição em casos de crimes tipificados como infrações disciplinares

Quando incide o disposto no art. 142, $\S 2^{\circ}$, da Lei no 8.112/90, que trata do prazo prescricional para a Administração Pública punir crimes classificados no estatuto disciplinar dos servidores públicos como faltas administrativas?

De fato, questão que merece aprofundada reflexão é sobre os casos em que a Administração Pública pode computar os prazos prescricionais da lei penal para aplicar penalidades disciplinares a servidores públicos quando o crime é previsto, no estatuto do funcionalismo, como causa de punição.

Reza a Lei $n^{\circ} 8.112 / 90$ : “\$2 $2^{\circ}$ Os prazos de prescrição previstos na lei penal aplicam-se às infrações disciplinares capituladas também como crime" (art. 142).

Questão crucial é conhecer a origem do dispositivo em apreço e saber a que o preceptivo legal alude quando menciona as "infrações disciplinares capituladas também como crime".

Origem do dispositivo do art. $142, \S 2^{\circ}$, da Lei $n^{\circ} 8.112 / 90$ e conceito de falta disciplinar que também constitui crime

O preceito do art. 142, $\S 2^{\circ}$, da Lei ${ }^{\circ}$ 8.112/90, é mera reprodução do disposto no parágrafo único do art. 213 da revogada Lei $n^{\circ}$ 1.711/1952 (antigo Estatuto dos Funcionários Públicos da União): "A falta também prevista na lei penal como crime prescreverá juntamente com este".

E o que é a falta administrativa ou infração disciplinar (na terminologia da Lei $\left.\mathrm{n}^{\circ} 8.112 / 90\right)$ prevista também como crime?

Responde-o o emérito Ministro Moreira Alves, explicando que

A \& C R. de Dir. Administrativo e Constitucional, Belo Horizonte, ano 6, n. 26, p. 161-198, out./dez. 2006 
falta administrativa ou disciplinar é toda aquela assim prevista no estatuto dos servidores públicos ou em lei administrativa que disponha sobre desvios de conduta funcional praticados por servidor público. Consigna, ainda, que o ilícito administrativo preexistia, antes de se tornar, por sua gravidade, um crime.

Com efeito, doutrinou o Ministro Moreira Alves, reportando-se, em voto proferido no Supremo Tribunal Federal, ao teor de lição de Caio Tácito ${ }^{1}$ sobre o histórico da tramitação legislativa da proposta que desaguou na elaboração do dispositivo do art. 213, parágrafo único, da revogada Lei $\mathrm{n}^{\circ} 1.711 / 1952$ (hoje reproduzido no art. 142, $\S 2^{\circ}$, da Lei $\mathrm{n}^{\circ} 8.112 / 90$ - destaques não originais):

(...) Parágrafo único. As faltas também previstas na legislação penal como delito, prescrevem juntamente com este, se não houver sentença condenatória. 3. É oportuno transcrever a justificativa do acréscimo: "As faltas disciplinares passam do dominio do direito administrativo para a esfera do direito penal, embora continuando residualmente no primeiro, quando vulneram certos direitos que merecem maior proteção". Bem se expressa Franz Von Lisst ao reconhecer que a razão por que, nessa hipótese, a punição disciplinar por si só insuficiente reclama um quid pluris (...) Ora, se nesse entendimento com o conteúdo do direito administrativo vai enriquecer o Código Penal, as normas da prescrição não ficam indiferentes: noutras palavras, se os crimes ditos contra a Administração, tipificados no Código Penal, estão sob o amparo da prescrição penal, por que motivo não introduzir esse instituto também no âmbito administrativo (...) Eis a lição de Themístocles Cavalcanti, luminar do direito administrativo entre nós: "A norma disciplinar precedeu, no tempo, à norma penal e já o fato constituía falta disciplinar antes que o legislador penal o tivesse considerado criminoso" (...) A pena de demissão prevista naquele iter sempre decorre de um procedimento criminoso do funcionário. Para exemplificar. A pena de demissão se aplica a quem abandonar o cargo; a quem empregar irregularmente os dinheiros públicos; a quem revela segredos; a quem se deixa corromper. Nessas hipóteses, em que se impõe a pena de demissão, ou se aplica o item II do artigo 209 ou se aplica o seu parágrafo único, porque também houve crime (...) Em que sentido se alude à obediência ao disposto na lei penal? O preceito é vago e merece ser aclarado. Diga-se que "a falta também prevista na lei penal como crime, prescreverá juntamente com este" e ter-se-á introduzido no projeto dispositivo côngruo. Esta a origem histórica do dispositivo que assim se enuncia, na lei vigente. ${ }^{2}$

Da lição doutrinária de Caio Tácito, endossada pela cátedra luminar do preclaro Ministro Moreira Alves, explica-se que os ilícitos administrativos existiram primeiro e não eram capitulados no âmbito do direito penal, mas, devido à gravidade das infrações disciplinares, elas passaram à

\footnotetext{
1 Revista de Direito Administrativo, v. 45, p. 412-456.

2 BRASIL. Supremo Tribunal Federal. Tribunal Pleno. Mandado de Segurança n 20.069/DF. Relator: Min. Moreira Alves. Brasília, DF, 24 nov. 1976. DJ, Brasília, DF, 02 set. 1977.
} 
categoria de crimes. Nessas hipóteses é que se pode afirmar que a falta administrativa também constitui delito criminoso e, por isso, em princípio, o prazo prescricional para punição dessas transgressões disciplinares será o estipulado na lei criminal (art. 142, §2 , Lei ${ }^{\circ}$ 8.112/90).

Patenteia-se que o dispositivo atual do art. $142, \S 2^{\circ}$, da Lei $n^{\circ}$ 8.112/90, se refere, portanto, aos crimes contra a Administração Pública, definidos nos artigos 312 a 326 do Código Penal, e em algumas normas legais esparsas, como a Lei Federal $n^{\circ}$ 6.766/1979 (art. 50, I a III). É nesses casos que se devem computar os prazos prescricionais para imposição de penalidades administrativas pelos marcos cronológicos da legislação criminal, porquanto essas infrações é que sempre foram, antes de se converterem em ilícitos penais, faltas disciplinares.

Os ilícitos disciplinares não eram infrações criminais, mas meras transgressões dos deveres e do regime funcional dos servidores públicos. O agente público patrocinava interesse privado perante a Administração, deixava de praticar ato de ofício para satisfazer interesse pessoal, recebia ou exigia propina para o exercício de suas funções, abandonava o cargo público de forma intencional, deixava de punir o seu subordinado por mera condescendência com o faltoso, enfim, cometia diversas condutas irregulares que não surtiam efeitos para a órbita do direito penal, embora representassem graves ofensas ao código disciplinar.

Somente mais tarde, em face do interesse da sociedade no regular funcionamento da Administração Pública e do prejuízo à coletividade causado pelas infrações cometidas pelos servidores, é que certos ilícitos disciplinares foram também albergados pelo direito penal.

Aí é que as faltas administrativas se tornaram aquelas que também se constituíram crimes (contra a Administração Pública), aludidas pelo $\S 2^{\circ}$ do art. 142 da Lei $\mathrm{n}^{\circ}$ 8.112/90, mera reprodução do dispositivo do art. 213, parágrafo único, da Lei $\mathrm{n}^{\mathrm{o}}$ 1.711/1952 (antigo Estatuto dos Funcionários Públicos da União, revogado pela Lei no 8.112/90).

Confirma-o Carlos S. de Barros Júnior:

Há faltas disciplinares que, pela sua maior gravidade, pelo seu caráter doloso, constituem também crimes. Elas configuram violação de deveres relativos à disciplinar e, do mesmo passo, atos previstos na lei penal. Prevê, assim, a lei disciplinar faltas que o Código Penal também reprime, considerando-as delitos. São os denominados crimes praticados por funcionários contra a Administração Pública. ${ }^{3}$

Crimes comuns à luz da regra do art. $142, \S 2^{\circ}$, da Lei $\mathrm{n}^{\circ} 8.112 / 90$

A \& C R. de Dir. Administrativo e Constitucional, Belo Horizonte, ano 6, n. 26, p. 161-198, out./dez. 2006 
Não se dá o mesmo no caso dos crimes comuns, pois não eram nem são, em essência, ilícitos disciplinares que se tornaram, por sua gravidade, infrações penais, mas sempre foram e continuam a ser, ontologicamente, condutas tipificadas na seara criminal, visto que não se originaram, em essência, de faltas administrativas anteriores. Ao contrário, a violação de sepultura, o estupro, o seqüestro, o homicídio, o estelionato, dentre outras infrações penais comuns, não vieram a lume a partir de uma falta administrativa, de um ilícito disciplinar precedente. Sempre tiveram justificativa e natureza própria, desvinculada, em sua essência, de comportamentos praticados contra a Administração Pública por servidores públicos, mas, sim, decorrem de atentados contra valores fundamentais cuja violação ofende a sociedade.

Se, segundo Caio Tácito, a regra da contagem dos prazos prescri-

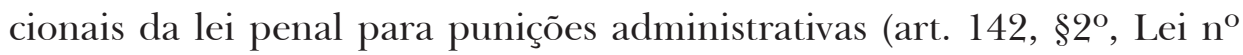
8.112/90, antigo parágrafo único do art. 213 da Lei $\mathrm{n}^{\circ} 1.711 / 1952$ ) se aplica às infrações administrativas que vieram a ser tipificadas criminalmente, resta inquestionável, pois, que é aos crimes contra a Administração Pública que o preceptivo em alusão deve ser aplicado, não nas hipóteses em que crimes comuns são praticados por servidores públicos, sobretudo quando as infrações penais nem sequer são previstas expressamente, no estatuto do funcionalismo, como falta funcional passível de punição.

Vicente Ferrer Correia Lima sufraga:

O Estatuto dos Funcionários abriga em seu bojo a punição para determinadas violações que, em alguns casos, também constituem crimes, as quais, apuradas que sejam em processo administrativo, devem igualmente ser investigadas através de inquérito policial, iniciado com as peças extraídas do referido processo administrativo (...) As caracterizações desses crimes e as penas respectivas são objeto dos artigos 312 e 326 do Código Penal que, para os efeitos penais, conceitua a figura do funcionário público no artigo $327 .{ }^{4}$

Petrônio Braz salienta: "A responsabilidade penal pelas ilicitudes praticadas pelo servidor público contra a Administração vêm capituladas nos arts. 312 a 327, do Código Penal brasileiro e na Lei n 8.666/93." ${ }^{\circ}$

\section{Crítica parcial à jurisprudência do Superior Tribunal de Justiça na interpretação do art. $142, \S 2^{\circ}$, da Lei $n^{\circ} 8.112 / 90$, no caso de cri- mes comuns, e comentários sobre os reflexos do princípio da legali-}

\footnotetext{
${ }^{3}$ BARROS JÚNIOR. Do poder disciplinar na administração pública, p. 103-104.

${ }^{4}$ LIMA. Ensaio jurídico sobre o processo ou inquérito administrativo, p. 77-78.

${ }^{5}$ BRAZ. Manual de direito administrativo, p. 539.
} 
dade na enumeração das faltas disciplinares: a questão da tipicidade e da discricionariedade no direito administrativo disciplinar

Não se abona a linha jurisprudencial esposada pelo Superior Tribunal de Justiça, data maxima venia, quando aplica, de forma irrestrita, o dispositivo do $\S 2^{\circ}$ do art. 142 da Lei $n^{\circ} 8.112 / 90$ para o fim de computar os prazos da lei penal para punições administrativas, ainda que os crimes comuns não sejam tipificados, expressa e especificamente, no estatuto dos servidores públicos, como falta funcional passível de punição.

Isso porque os crimes comuns podem ser causa de demissão ou de aplicação de outra penalidade, desde que especificamente tipificados como faltas administrativas no estatuto disciplinar.

Se não o forem, todavia, não passam de ilícitos penais, punidos pela autoridade judiciária com penas criminais, sendo vedado ao administrador público aplicar sanção disciplinar se os crimes comuns não são causa expressamente prevista de demissão ou pena administrativa, sob pena de ofensa ao princípio da legalidade.

Poder-se-ia até admitir que, uma vez que o ilícito penal seja previsto, de forma autônoma, como infração disciplinar, aí sim os prazos prescricionais a serem observados sejam os da lei penal, embora não seja essa a idéia original preconizada no dispositivo do art. 213, parágrafo único, da Lei $\mathrm{n}^{\mathrm{o}} 1.711 / 1952$, reproduzido na atual redação do art. 142 , $\S 2^{\circ}$, da Lei $\mathrm{n}^{\mathrm{o}} 8.112 / 90$, como explicado no item precedente.

Se, entretanto, o crime não é causa expressa de demissão, assim tipificado no estatuto dos servidores públicos, será impertinente computar os prazos prescricionais da lei penal para fins de contagem do tempo para eventual punição administrativa na verdade vedada, visto que a Administração Pública não poderá motivar pena disciplinar pela prática de crime se inexiste previsão legal autorizativa.

\section{Crimes contra a Administração Pública, como infração disciplinar passível de demissão expressamente prevista no estatuto dos ser- vidores públicos federais}

Por que é lícito demitir o servidor público por cometer peculato, abandono de cargo, concussão, advocacia administrativa, violação de segredo funcional, corrupção passiva? Porque esses fatos criminosos são previstos como causa de demissão no art. 132, I, da Lei no 8.112/90, que tipifica como motivo de penalidade demissória o cometimento de crime contra a Administração Pública (exatamente os previstos nos arts. 
312 a 326 do Código Penal, além dos que assim sejam definidos em lei extravagante).

Por que a Lei $\mathrm{n}^{\mathrm{o}} 8.112 / 90$ se preocupou em relacionar entre as causas de demissão (art. 132, incisos I, como a violação de sigilo funcional, o desvio de verbas públicas, o abandono de cargo, a prática de crimes contra a Administração Pública), fatos que são também crimes definidos no Código Penal, portanto tornando os ilícitos penais também infrações disciplinares, se fosse possível à Administração Pública punir todo e qualquer fato, inclusive crimes comuns, como fatos geradores de responsabilidade administrativa, independentemente de previsão legal? Contém o texto da lei, então, palavras inúteis ou uma série de dispositivos desnecessários, já que o Estado poderia, aleatória e indiscriminadamente, apenar qualquer fato, mesmo que não fosse previsto, no estatuto disciplinar do funcionalismo, como causa de punição?!

A Lei $n^{\circ} 8.112 / 90$ é clara no sentido de que somente se estendem pelos prazos prescricionais da lei penal as infrações administrativas tipificadas no estatuto disciplinar do funcionalismo que, simultaneamente, constituem crimes (art. 142, §2 , Lei n ${ }^{\circ} 8.112 / 90$ ) — é precisamente o caso dos crimes contra a Administração Pública (arts. 312 a 326, Código Penal, como o peculato, concussão, corrupção passiva, advocacia administrativa).

Isto é, o fato é previsto na legislação administrativa como falta e é também apenado com pena criminal no Estatuto Penal pertinente.

Não é o caso, por exemplo, da falsidade ideológica (art. 299, Código Penal), que não é expressamente prevista como infração administrativa na Lei $n^{\circ} 8.112 / 90$, mas tão-somente no Código Penal.

Por exemplo, o abandono de cargo é tipificado no Código Penal (art. 323) e na Lei n ${ }^{\circ}$ 8.112/90 (art. 138). A corrupção, capitulada no art. 317, do Código Penal, e no art. 132, XI, da Lei n ${ }^{\circ}$ 8.112/90; a aplicação irregular de dinheiro público, se ocorre desvio (art. 132, VIII, Lei no 8.112/90) e o peculato, na forma de desvio de recursos públicos (art. 312, Código Penal).

Palhares Moreira Reis comenta que a Lei no 8.112/90 previu, como falta disciplinar tipificada, a aplicação irregular de dinheiros públicos (art. 132, VIII), também conceituada como crime no art. 315, do Código Penal; a revelação de segredo do qual o servidor se apropriou em razão do cargo é capitulada como infração administrativa (art. 132, IX, Lei $\mathrm{n}^{\mathrm{o}} 8.112 / 90$ ) e como ilícito criminal (art. 325, Código Penal), assim como 
a corrupção como falta disciplinar (art. 32, XI, Lei no 8.112/90) e crime (art. 317, Código Penal). ${ }^{6}$

\section{Princípio da legalidade na imposição de sanções e a tipicidade de infrações disciplinares}

É que a pena de demissão, a mais grave cabivel contra o servidor público em atividade, por força do princípio da legalidade da Administração Pública, somente pode ser aplicada se houver, expressamente, uma descrição da conduta passível dessa punição no estatuto do funcionalismo. Se não houver, a punição deverá basear-se em algum dispositivo da lei disciplinar aplicável ao servidor processado que defina uma infração disciplinar pura (só que, nesse caso, os prazos prescricionais serão os do art. 142, I a III, da Lei n ${ }^{\circ} 8.112 / 90$ ).

É a lição de Marçal Justen Filho, o qual acentua que se aplica o princípio da legalidade no tocante à definição das infrações e na fixação das sanções e, quanto à pena de demissão, frisa: "A gravidade da sanção impede sua aplicação sem previsão legal das hipóteses de seu cabimento."7

É preciso deixar claro que a responsabilidade administrativa decorre, por força do princípio da legalidade, de a conduta dos servidores públicos configurar infrações disciplinares, capituladas em regras do respectivo estatuto funcional. Já a responsabilidade criminal resulta da adequação típica da conduta em um dos modelos de infrações estatuídas no Código Penal ou legislação repressiva pertinente. Necessariamente, a conduta se deve enquadrar em uma previsão normativa de ilícito, seja administrativo, seja criminal.

Vicente Ferrer Correia Lima explicita essa idéia de tipicidade:

Somente são punidas, penal e administrativamente, as infrações que estiverem, específica ou genericamente, caracterizadas nos respectivos diplomas legais, isto é, no Código Penal, no Estatuto dos Funcionários ou leis correlatas. Nem ao Juiz, nem à autoridade administrativa, é permitido instituir crimes, faltas e penas. ${ }^{8}$

Para que se possa falar de responsabilidade administrativa e de imposição de penas disciplinares, mister que exista uma conduta classificada em lei funcional definidora de infração administrativa, isto é, o fato cometido pelo servidor deve ser previsto, no estatuto disciplinar, como ilícito administrativo.

\footnotetext{
6 REIS. Processo disciplinar, p. 289-290.

7 JUSTEN FILHO. Curso de direito administrativo, p. 665, 674.

8 LIMA. Ensaio jurídico sobre o processo ou inquérito administrativo, p. 93-94.
} 
Cármen Lúcia Antunes Rocha explicita: “Demissão, no sistema brasileiro, é pena. Logo, somente pode ocorrer quando houver previsão legal da falta autorizativa de tal decisão."9

É condição sine qua non, se o modelo legislativo adotado prevê exaustivamente as infrações disciplinares (como é o caso do art. 132, da Lei $n^{\circ} 8.112 / 90$, ao taxativamente relacionar as ações passíveis de demissão), que a conduta se enquadre em um dos tipos disciplinares elencados, sob pena de agressão ao princípio da legalidade, pois a autoridade administrativa estaria criando ilícitos por meio de ato administrativo, o que não se coaduna com o império da lei em exclusivamente definir infrações e sanções disciplinares.

\section{Tendências da tipicidade das faltas sujeitas a penas mais graves no direito administrativo disciplinar: discricionariedade e tipos aber- tos e fechados de infrações administrativas: o modelo da ordem jurídica federal}

No que concerne às penas mais severas, a tendência do direito administrativo disciplinar, em virtude dos avanços democráticos, é de regular o mais precisamente possível as faltas, em tipos disciplinares, deixando margem maior para discricionariedade administrativa somente para as condutas sujeitas a penas mais leves.

Veja-se que, embora possível que a lei crie infrações disciplinares com tipo aberto e com margem discricionária para enquadramento pela autoridade administrativa (por exemplo: “o servidor será demitido se cometer grave violação de seus deveres" ou "se incorrer em procedimento irregular gravíssimo"), não é essa a tendência dos estatutos pátrios, particularmente no modelo da Lei Federal $n^{\circ} 8.112 / 90$, que tipifica as condutas passíveis de penalidade demissória em modelos hipotéticos cujos elementos do tipo disciplinar respectivo são precisos ou rendem pequena margem para discricionariedade. Aliás, o Estatuto dos Funcionários Públicos federais de 1939 (Decreto-lei $n^{\circ}$ 1.713/1939) capitulava que seria aplicada a pena de demissão em caso de "procedimento irregular do funcionário, devidamente comprovado" (art. 238, III), de natureza discricionária ampla, mas que nem sequer foi reproduzido na Lei Federal $n^{\mathrm{o}} 1.711 / 1952$ (Estatutos dos Funcionários Públicos federais), nem

${ }^{9}$ ROCHA. Princípios constitucionais dos servidores públicos, p. 452. 
menos ainda na posterior Lei Federal no 8.112/90.

De fato, as infrações passíveis de demissão são claras e de conteúdo normativo e fático definido: crime contra a administração pública (art. 132, I, Lei $\mathrm{n}^{\mathrm{O}}$ 8.112/90), abandono de cargo (art. 132, II, c.c. art. 138, Lei $\mathrm{n}^{\mathrm{O}}$ 8.112/90); inassiduidade habitual (art. 132, I, c.c. art. 139, Lei $\mathrm{n}^{\mathrm{o}}$ 8.112/90); improbidade administrativa (art. 132, IV, Lei $\mathrm{n}^{\circ}$ 8.112/90); ofensa física, em serviço, a servidor ou a particular, salvo em legítima defesa própria ou de outrem (art. 132, VII, Lei no 8.112/90); aplicação irregular de dinheiros públicos (art. 132, VIII, Lei $n^{\circ}$ 8.112/90, c.c. art. 315, Código Penal); revelação de segredo do qual se apropriou em razão do cargo (art. 132, IX, Lei no 8.112/90, c.c. art. 325, Código Penal); lesão aos cofres públicos e dilapidação do patrimônio nacional (art. 132, X, Lei no 8.112/90); corrupção (art. 132, XI, Lei no 8.112/90); acumulação ilegal de cargos, empregos ou funções públicas (art. 132, XII, Lei $n^{\circ}$ 8.112/90); transgressão dos incisos IX a XVI do art. 117 da Lei $\mathrm{n}^{\mathrm{o}} 8.112 / 90$, prevista no art. 132, XIII, Lei no $8.112 / 90$ : (valer-se do cargo para lograr proveito pessoal ou de outrem, em detrimento da dignidade da função pública; participar de gerência ou administração de sociedade privada, personificada ou não personificada, salvo a participação nos conselhos de administração e fiscal de empresas ou entidades em que a União detenha, direta ou indiretamente, participação no capital social ou em sociedade cooperativa constituída para prestar serviços a seus membros, e exercer o comércio, exceto na qualidade de acionista, cotista ou comanditário; atuar, como procurador ou intermediário, junto a repartições públicas, salvo quando se tratar de benefícios previdenciários ou assistenciais de parentes até o segundo grau, e de cônjuge ou companheiro; receber propina, comissão, presente ou vantagem de qualquer espécie, em razão de suas atribuições; aceitar comissão, emprego ou pensão de estado estrangeiro; praticar usura sob qualquer de suas formas; utilizar pessoal ou recursos materiais da repartição em serviços ou atividades particulares; cometer a outro servidor atribuições estranhas ao cargo que ocupa, exceto em situações de emergência e transitórias).

São infrações, portanto, de conteúdo preciso, para cuja configuração não se confere margem discricionária ao aplicador do direito ou, quando muito, facultam pouca discricionariedade para a autoridade administrativa proceder ao enquadramento das faltas disciplinares nesses tipos.

Já os seguintes tipos disciplinares, que relacionam causas de de- 
missão, conquanto possam conferir alguma faixa de discricionariedade para o administrador público em capitular os fatos irregulares cometidos pelos servidores infratores nessas disposições normativas, têm, entretanto, seu conteúdo e densidade comentados e precisamente circunscritos pela doutrina, a qual delimita a interpretação desses ilícitos. Eis os preceptivos: proceder de forma desidiosa (art. 117, XV, c.c. art. 132, XIII, Lei $\mathrm{n}^{\mathrm{o}}$ 8.112/90); incontinência pública e conduta escandalosa, na repartição (art. 132, V, Lei $\mathrm{n}^{\mathrm{o}}$ 8.112/90); insubordinação grave em serviço (art. 132, VI, Lei $\left.\mathrm{n}^{\mathrm{o}} 8.112 / 90\right)$.

\section{Evolução quanto à idéia inicial do direito francês de desnecessi- dade de previsão legal das infrações disciplinares, senão apenas das sanções aplicáveis: perspectiva corrente no direito brasileiro e estrangeiro}

Constata-se que a idéia antiga, do direito francês, de que as infrações disciplinares não careceriam de previsão legal (nem se lhes aplicaria a exigência de tipicidade como no direito penal), podendo ser punidas todas as condutas dos servidores que infrinjam deveres funcionais em sentido amplo (sem sequer a enunciação das infrações passíveis de penas mais graves, mas somente com a descrição do rol de penalidades cabíveis), tem cedido terreno para a obrigatoriedade de previsão legal, taxativa, das faltas sujeitas a penalidades de demissão, cassação de aposentadoria ou disponibilidade, em nome do princípio da legalidade.

José Bernejo Vera defende a tipicidade das faltas disciplinares:

La reserva de Ley cubre principalmente la tipificación de las infracciones (penales y administrativas) y la determinación de los castigos correspondientes (penas o sanciones administrativas) (...) tiene que ver siempre una norma con rango de Ley la que contenga una verdadera tipificación de lãs infracciones y la que señale con tanta precisión como le sea posible las sanciones pertinentes y las reglas sobre responsabilidad (...) Establecer como elementos esenciales de la infracción administrativa los mismos de la infracción del Derecho Administrativo sancionador al Derecho Penal a que hemos aludido antes. Lo cierto es que el TS lo ha proclamado reiteradamente. Por ej., su sentencia de 17 de abril de 1990, entre otras similares, define la infracción administrativa como "conducta antijurídica, típica y culpable". Y la STS de 23 de febrero de 2000 (Ar. 7047) afirma: "Para que una determinada acción u omisión pueda ser objeto de sanción es necesario que sea típica, antijurídica y culpable; presupuestos que quedan eliminados por la concurrencia de causas de justificación o excluyentes de la culpabilidad o antijuridicidad. (...) Para que un conducta sea infracción administrativa es necesario que, además de ser antijurídica, este concretamente prevista por una norma como tal infracción y tenga atribuida

A \& C R. de Dir. Administrativo e Constitucional, Belo Horizonte, ano 6, n. 26, p. 161-198, out./dez. 2006 
una sanción administrativa. Las normas sancionadoras, como las penales, acotan una parte de las conductas antijurídicas para convertirlas en infracciones administrativas. Las normas establecen los "tipos". En este sentido se habla del requisito de la tipicidad de la conducta: sólo son infracciones las acciones $\mathrm{u}$ omisiones tipificadas como tales o, lo que expresa la misma Idea, las conductas "típicas". La acción u omisión antijurídica pero no típica no constituye infracción ni puede ser castigada, sin perjuicio de que si lê correspondan otras consecuencias. ${ }^{10}$

Sim, a propalada atipicidade das faltas disciplinares, se comparadas à previsão dos crimes no direito penal, deve ser compreendida como a possibilidade de existirem tipos disciplinares, relativamente abertos (caso dos preceptivos dos artigos 117, XV, 132, V e VI, todos da Lei Federal $n^{\circ} 8.112 / 90$ ), cujos elementos podem ser interpretados com relativa margem discricionária pelo administrador público, o qual poderá considerar que certa conduta constitui, ou não, por exemplo, ato de insubordinação grave. No direito penal, os tipos são, em regra, fechados, cujos elementos contêm palavras e ações cujo conteúdo é conhecido ou exaurido na doutrina penalista, não facultando margem para discricionariedade de tipificação, ressalvada a figura das normas penais em branco, completadas por atos normativos administrativos outros, como os crimes de posse de substância entorpecente (o conceito dessa substância é definido em lei ou regulamento administrativo) ou de omissão em notificar doença contagiosa (a relação de doenças de notificação compulsória é definida em regulamento administrativo).

\section{Os limites da discricionariedade administrativa no Estado demo- crático de Direito: a consagração da tipicidade das faltas sujeitas a sanções mais graves no direito positivo federal brasileiro e na doutrina desde o Estatuto dos Servidores Públicos Federais de 1939}

O que não se pode abonar é o raciocínio de que o Estado poderia editar uma norma com um único dispositivo acerca da responsabilidade dos servidores públicos ("o servidor será punido, com as penas previstas nesta lei, se violar dever ou proibição funcional”), sem que exista a relação dos deveres e proibições e a previsão das penas cabíveis para cada espécie de conduta, com o fim de se permitir à autoridade administrativa vasta $\mathrm{e}$ irrestrita liberdade para avaliar todo e qualquer fato e aplicar, conforme

\footnotetext{
${ }^{10}$ VERA. El derecho administrativo sancionador. In: MOREIRA NETO. Uma avaliação das tendências contemporâneas do direito administrativo: anais do seminário de Direito Administrativo Brasil-Espanha, obra em homenagem a Eduardo García de Enterría, p. 271-272, 280, 283.
} 
seu alvedrio e até arbítrio, a punição que achar melhor. Registre-se, por sinal, que, no direito brasileiro, os estatutos dos funcionários públicos federais de 1939 e 1952 já fixavam, taxativamente, as hipóteses de aplicabilidade de pena de demissão, tradição mantida, com rigor, no texto da atual Lei Federal $n^{\circ}$ 8.112/90.

Henrique de Carvalho Simas, comentando o Estatuto dos Servidores Públicos Federais de 1952, revogado pela Lei no $8.112 / 90$, mas mantido basicamente nas disposições do atual estatuto, explica:

No propósito de impedir ou dificultar o abuso das autoridades, dando aos fun-
cionários maior garantia contra possíveis desmandos e arbitrariedades, a Norma
Jurídica, nas Nações democráticas e como corolário do princípio da legalidade,
relaciona as faltas administrativas e suas penas disciplinares (...) o Estatuto fede-
ral de 1952, para evitar excessos na imposição da pena máxima, enumerou, no
art. 207, de forma taxativa, os casos possíveis de sua aplicação (...) A demissão
distingue-se por ser uma pena disciplinar que a lei prevê em caso de graves
infrações especialmente configuradas. A demissão não se decreta a livre critério
do administrador. ${ }^{11}$

Entendimento em contrário seria fugir ao princípio constitucional da legalidade, além de produzir o efeito de esvaziar o princípio da moti-vação da atuação administrativa, porquanto não somente os crimes comuns, mas até os atos da vida privada, além de qualquer ação ou omissão cometida por servidor público, poderiam ser livre e irrestritamente conceituados como falta disciplinar por autoridades da Administração Pública, as quais poderiam ter "carta branca" para impor quaisquer sanções em um Estado democrático de Direito, pior ainda porque poderiam invocar poderes estritamente discricionários, ilimitados, para tentar afastar o eventual controle jurisdicional sobre os atos administrativos, trazendo de volta à seara administrativa os tempos negros do arbítrio.

Criticando os abusos que a discricionariedade da Administração Pública em enquadrar como "procedimento irregular" diversas condutas do servidor, inclusive a ponto de nem os órgãos administrativos de consultoria jurídica oficiais nem sequer o Poder Judiciário definirem a densidade e o conteúdo normativo precisos dessa falta disciplinar, Olavo Tabajara Silveira não abona a amplitude conceitual que o DASP emprestava ao tipo de ilícito funcional em destaque, considerando compreendido na idéia normativa todo procedimento oposto à justiça, à lei ou contrário aos princípios de moral com que se deve mover o

11 SIMAS. Manual elementar de direito administrativo, p. 485. 
funcionário. O doutrinador pontua:

Sua imprecisão implicava, segundo diziam, em gerar situação de permanente insegurança para o servidor público, em contradição, aliás, com a própria estabilidade garantida pela Carta Magna (...) O pecado maior que se tem verificado, com lamentável freqüência, é o do recurso à invocação do "procedimento irregular", quando nada se consegue apurar em maltratados inquéritos administrativos (...) A figura disciplinar em causa não poderá, jamais, ser erigida em recurso para aproveitamento de processos natimortos ou mal orientados. ${ }^{12}$

Ora, um quadro dessa expressão colide com todos os avanços já consagrados na doutrina e na jurisprudência do direito administrativo no Brasil, haja vista a tendente linha jurisprudencial de controle de legalidade dos atos administrativos disciplinares sob a ótica dos princípios constitucionais da proporcionalidade, razoabilidade, individualização da pena (até da insignificância), motivação, com o efeito de o Poder Judiciário anular penalidades impostas de forma exagerada, incompatível com a menor gravidade das condutas, ou à revelia das circunstâncias atenuantes e demais parâmetros de dosimetria das sanções, quando inadequada a penalidade infligida diante dos motivos fáticos que a determinaram, sem falar na sindicância judicial da própria correção quanto à capitulação jurídica do fato e, especialmente, acerca da possibilidade efetiva de defesa quanto às acusações deduzidas.

Não se admite possa a autoridade administrativa punir indiscriminadamente os agentes públicos, nem menos ainda instituir faltas disciplinares por ato infralegal, nem que resida absoluta insegurança jurídica da parte dos servidores quanto ao conhecimento, decorrente de clara previsão legal, das condutas passíveis de apenação mais grave.

Daí a tendência do direito administrativo disciplinar atual de tipicidade das faltas disciplinares cominadas com penas mais graves, admitindo-se pequena parcela de discricionariedade no enquadramento de algumas condutas (como a demissão por "ato de insubordinação grave"), enquanto absoluta tipicidade quanto a outras, cujos elementos típicos são rigorosa e precisamente enunciados (como, por exemplo, abandono de cargo, inassiduidade habitual, prática de crime contra a Administração Pública, etc.).

A tendência da tipificação das faltas administrativas é apontada por Justino Vasconcelos:

\footnotetext{
12 SILVEIRA. O funcionário público, p. 93-94.
} 
Não se deve exagerar crendo que o poder disciplinar seja, ou possa ser, livre de vínculos. Antes de tudo, é exigência de uma boa ordem jurídica se prevejam com amplitude as possíveis infrações disciplinares e se fixem, com precisão, as sanções correspondentes. Subsiste, assim, a tendência de estabelecer, com normas jurídicas, a noção de falta disciplinar e a natureza e entidade da pena, segundo o preceito "nullum crimen sine lege", de graduar a pena, de agravá-la pela reincidência, de presumir a inocência do acusado, e de instituir procedimentos contenciosos para a aplicação das penas disciplinares. Tendência idêntica se verifica relativamente à individualização e previsão da falta disciplinar no texto legal, acomodando-a ao princípio que condiciona a configuração e a punibilidade do delito. ${ }^{13}$

\section{Regis Fernandes de Oliveira aponta:}

No campo do Direito Administrativo prevalece o que se rotula de tipicidade, isto é, a infração administrativa há que se estar devidamente delimitada pela regra normativa. As exigências são as mesmas que aquelas para identificação dos crimes. A garantia da Administração para obstar qualquer ação infracional ou arbitrária do agente público, está em que deve ela pautar sua conduta pelos ditames legais. ${ }^{14}$

Pedro Guillermo Altamira anota que a incidência do princípio da tipicidade do direito penal deve incidir, no possível, na punição das faltas disciplinares, para prevenir arbitrariedade: "En derecho penal rige el principio nulla poena sine lege que en lo posible debe hacerse extensivo a la 'potestad'disciplinaria, dejando escaso margen a la discrecionalidad para evitar la arbitrariedad." 15

\section{Responsabilidade administrativa e tipicidade de infrações disci- plinares}

Conseqüentemente, é descabido falar em responsabilidade administrativa e em demitir do serviço público, se o fato não é previsto, no estatuto dos servidores, como falta passível de demissão ou cassação de aposentadoria, seja um crime contra a Administração Pública, um crime comum ou mesmo um ilícito exclusivamente disciplinar expressamente tipificado, sob pena de se reconhecerem poderes ao administrador público de criar faltas disciplinares quando a lei não o fez.

Ainda, se não existe previsão legal do fato como causa de demissão dentre aquelas expressamente tipificadas no estatuto do funcionalismo, evidente que não será pertinente a incidência do disposto no art. 142, §2º da Lei $n^{\circ}$ 8112/90, que

\footnotetext{
${ }^{13}$ VASCONCELOS. Súmulas de legislação aplicável à função pública, p. 186-189.

${ }_{14}$ OLIVEIRA. Servidores públicos, p. 136.

${ }^{15}$ unción pública, p. 639.
} 
prevê a contagem dos prazos prescricionais fixados no Código ou na legislação Penal para responsabilização administrativa dos servidores pela prática de crime. Se a Administração Pública não pode demitir, cassar a aposentadoria ou a disponibilidade pela prática de crime comum, porque não tipificado na lei administrativa como infração disciplinar, resta prejudicada a contagem de marcos cronológicos da lei criminal para punição administrativa, uma vez que, se o fato não é punível, descabe falar de lapsos temporais para o exercício do direito de punir na esfera disciplinar.

O professor mexicano García-Trevijano Fos confirma que, no direito do México, é obrigatória a previsão em lei das infrações disciplinares, por força do princípio da legalidade:

Ninguna infracción disciplinaria existe mientras no se encuentre prevista em um texto normativo. Ahora bien, es preciso que estén enumeradas taxativamente? Técnicamente, así debería de ser, y, por tanto (...) El respeto al principio de legalidad es aquí total y nuestra jurisprudencia así lo ha establecido (SS. de 7 de abril de 1953, 28 de junio de 1960, 9 de noviembre de 1965, 20 de diciembre de 1967, etcétera...). La sentencia de 3 de febrero de 1969 sienta la doctrina de que "solo son faltas los hechos previstos como tales, sin que baste que sean reprochables", ya que la tipicidad juega (en este terreno) aunque sea atenuada, y exige siempre que estén previstas. ${ }^{16}$

A obrigatoriedade de previsão em lei das infrações disciplinares é corroborada por Eduardo Garcia de Enterría e Tomás-Ramón Fernández:

Não há infração nem sanção administrativas possíveis sem lei que as determine, de uma maneira prévia; em segundo lugar, essa previsão legal, que tem aqui além disso o caráter próprio da legalidade administrativa que conhecemos, a atribuição à Administração de potestade para sancionar, tem que realizar-se justamente através de lei formal (...) o princípio de tipicidade é uma aplicação daquele de legalidade e exige, como sabemos, a delimitação concreta das condutas que são reprováveis a efeitos de sua sanção. A jurisprudência contenciosa recorda esta exigência nas sanções administrativas. Hoje esta particularidade está expressa no art. 25, 1, da Constituição; a lei há de ter determinado de maneira prévia que "ações ou omissões" em concreto constituem infração administrativa, o que exclui cláusulas abertas ou indeterminadas. ${ }^{17}$

Carlos S. de Barros Júnior parece encampar essa idéia de obrigatória previsão estatutária dos crimes como faltas disciplinares, aludindo ao Estatuto dos Servidores federais de 1939 (art. 239, II), quando referia

\footnotetext{
${ }^{16}$ GARCIA-TREVIJANO FOS. Tratado de derecho administrativo, p. 971.
} 
que seria aplicada a pena de demissão a bem do serviço publico ao funcionário que praticasse crime contra a boa ordem e administração pública, a fé pública e a Fazenda Nacional, ou previsto nas leis relativas à segurança e à defesa do Estado:

Determinou a lei estatutária de 1939 que, nos casos de crimes contra a boa ordem e administração pública, e, outros, enunciados no art. 239. n. II., daquele Estatuto, se efetivasse a responsabilidade disciplinar. ${ }^{18}$

Não pode, destarte, suceder punição disciplinar por fato ao qual o estatuto dos servidores públicos não prevê sanção.

\section{Caráter exaustivo das hipóteses de demissão, cassação de aposen- tadoria ou disponibilidade na disciplina da Lei $n^{\circ} 8.112 / 90$}

Carlos S. de Barros Júnior cita Tito Prates da Fonseca para afiançar que as penas expulsivas não se podem aplicar sem determinação legal e que é taxativa a enumeração dos tipos das faltas passíveis de demissão no estatuto disciplinar, ao mesmo tempo em que lembra o escólio de Marcelo Caetano no sentido de que existe "a tendência de fixar na lei os casos em que taxativamente é lícito aplicála (...) em face do nosso direito positivo, só as faltas enunciadas, como suscetíveis de demissão, podem acarretar essa penalidade."19 (grifo nosso).

Themistocles Brandão Cavalcanti aduz: "A aplicação da pena disciplinar pressupõe uma infração prevista e punida pela lei e uma pena também consignada por uma disposição legal." ${ }^{20}$ (grifo nosso)

Com efeito, a Lei no 8.112/90 previu, exaustivamente, no seu art. 132, as condutas sujeitas à pena de demissão. Faltas disciplinares ou comportamentos ali não previstos expressamente não podem ensejar a pena demissória.

A lição é encampada por Sebastião José Lessa, o qual cita Marcelo Caetano, Victor Nunes Leal e Hely Lopes Meirelles no sentido de que os motivos para a aplicação de pena demissória são vinculados, de maneira que os casos de demissão devem obedecer à regra da tipicidade, com a "prévia definição do comportamento e absoluta correspondência entre o tipo e a conduta." 1

Os estudiosos do direito administrativo disciplinar ${ }^{22}$ já encimam que a discricionariedade fica sobremodo restrita no caso de faltas passíveis de penas mais graves, que constituem atos vinculados, os quais somente podem ser aplicados se houver a presença, inequivocamente demonstrada

17 GARCIA DE ENTERRÍA; FERNÁNDES. Curso de direito administrativo, p. 894.

${ }^{18}$ BARROS JÚNIOR. Do poder disciplinar na administração pública, p. 104.

${ }^{19}$ BARROS JÚNIOR. Do poder disciplinar na administração pública, p. 129.

${ }^{20}$ CAVALCANTI. Tratado de direito administrativo, p. 441. 
nos autos do processo administrativo, dos motivos de fato previstos em lei para a imposição da demissão. Vigora a tipicidade das infrações mais graves.

É tendência dos estatutos disciplinares do funcionalismo público de relacionar, de forma exaustiva, os casos de condutas para as quais serão aplicadas a pena de demissão, como se vê no art. 132 e nos incisos IX a XVI do art. 117, todos da Lei $\mathrm{n}^{\circ} 8.112 / 90$.

$\mathrm{Na}$ verdade, a discricionariedade, em direito administrativo, existe nos termos da lei. Ato discricionário deve gozar de autorização legal, sob pena de se tornar ato arbitrário. Conseqüentemente, é na lei definidora do regime disciplinar dos servidores públicos que se alinharão os limites do poder discricionário do administrador público a quem outorgado o exercício do poder disciplinar.

Se o estatuto do funcionalismo, pois, estabelece faltas disciplinares cujo tipo admite discricionarismo para o enquadramento da conduta (por exemplo: será causa de demissão a prática de "procedimento irregular de natureza grave”), poderá ser aplicada punição correspondente por meio de classificação jurídica discricionária, observada lógica e aproximação estreita entre os fatos e a previsão normativa pertinente.

Se, todavia, o diploma legal capitula infrações disciplinares precisamente delineadas, não haverá margem a distorções no enquadramento jurídico, respeitandose a idéia de tipicidade estrita.

De todo modo, o que precisa ficar assentado é a tendência dos estatutos disciplinares do funcionalismo em tipificar, exaustivamente, as condutas passíveis de demissão, cassação de aposentadoria ou disponibilidade, definindo as infrações disciplinares de forma o mais precisa possível, a fim de subtrair da autoridade administrativa margem a arbítrio no manejo abusivo do poder de punir servidores públicos.

As penalidades disciplinares gravíssimas somente são aplicáveis

\footnotetext{
${ }^{21}$ LESSA, Sebastião José. Temas práticos de direito administrativo disciplinar. Brasília: Brasília Jurídica, 2005. p. 65.

22 José Armando da Costa também observa que as faltas passíveis de demissão devem ser tipificadas no estatuto disciplinar dos servidores públicos: "A base hipotética expressa vem descrita, pelo legislador, no Estatuto, tendo o seu contorno explicitamente delineado na norma. É utilizada, em regra, nas transgressões puníveis com sanções mais graves." José Armando da Costa, ponderando que as faltas mais graves são típicas, nota que "a regra da relativa tipicidade — predominante na área do Direito Disciplinar — é tãosomente aplicável nos casos de punições mais leves (...) O atual regime disciplinar (Lei n. ${ }^{\circ}$ 8.112/90) do servidor federal, deixando ao administrador público apenas uma diminuta potestade discricionária, se afilia à terceira posição (quase que absoluta tipicidade), uma vez que somente nos casos de penas de advertência poderá haver tal flexibilidade (art. 129)." (COSTA. Direito administrativo disciplinar, p. 207, 209).
} 
para as condutas previstas exaustiva (numerus clausus) e expressamente na lei disciplinadora da conduta funcional, como foi seguido no caso da Lei $\mathrm{n}^{\mathrm{o}} 8.112 / 90$ (somente admite demissão para os fatos ajustados aos tipos previstos no seu art. 132).

Até para a imposição de penas mais brandas, como a advertência e a suspensão, a Lei n ${ }^{\circ}$ 8.112/90 definiu os deveres e proibições cuja violação implicaria as respectivas penalidades (vide arts. 129 e 130), ressalvando pequena parcela residual de competência discricionária para o enquadramento jurídico dos fatos, como no caso de imposição de advertência aplicável por violação de dever funcional (art. 129, Lei n ${ }^{\circ}$ 8.112/90).

Oswaldo Aranha Bandeira de Mello frisa que a pena de demissão "supõe falta grave, enunciada em lei", ${ }^{23}$ no que é endossado por Mário Masagão: "O legislador entendeu de catalogar os casos de demissão, declarando nos Estatutos."24 (grifo nosso).

Também doutrina Odete Medauar: "As condutas consideradas infrações devem estar legalmente previstas; é ilegal apenar servidores públicos por atos ou fatos que não estejam caracterizados, na lei, como infrações funcionais. Essa caracterização se efetua nos estatutos e leis orgânicas das categorias, principalmente"25 (grifo nosso).

Nesse sentido é a orientação jurisprudencial do egrégio Tribunal Regional Federal da $1^{\mathrm{a}}$ Região:

A lei não concede, aliás nem poderia fazê-lo, uma autorização incondicionada aos administradores. A punição deve estar atrelada a um pressuposto fático, previamente catalogado como infração administrativa, para que ocorra a punição. ${ }^{26}$

\section{Previsão de crimes comuns como faltas disciplinares no estatuto dos servidores públicos como pressuposto para contagem dos prazos prescricionais da lei penal para punição administrativa}

Infere-se, de todo modo (ainda que se elastecesse a finalidade e sentido original do dispositivo do revogado parágrafo único do art. 213 da Lei $n^{\circ} 1.711 / 1952$, reproduzido no $\$ 2^{\circ}$ do art. 142 da Lei $n^{\circ} 8.112 / 90$, de aplicação restrita aos assim tipificados crimes contra a Administração Pública), que a Administração somente pode contar os prazos prescricionais pelas regras da lei penal quando o mesmo fato é tipificado, de forma autônoma, no estatuto

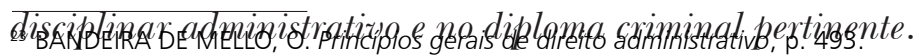

${ }^{24}$ MASAGÃO. Curso de direito administrativo, p. 247.

${ }^{25}$ MEDAUAR. Direito administrativo moderno, p. 354.

${ }^{26}$ BRASIL. Tribunal Regional Federal (1. Região). APC 1999.01.00.113141-7-DF. Relatora: Des. Federal Mônica Neves Aguiar Silva Castro. DJ, Brasília, DF, 19 maio 2000. Unânime. Citado por Sebastião José Lessa. In: LESSA, Sebastião José. Temas práticos de direito administrativo disciplinar. Brasília: Brasília Jurídica, 2005. p. 79. 
José Cretella Júnior anota que as leis administrativas municipais, estaduais e federais repetem delitos capitulados no Código Penal, na Lei das Contravenções, no Código Eleitoral, na Lei de Economia Popular, asseverando: "Os crimes não são punidos pela Administração pelo fato de constituírem crimes, mas por estarem definidos de maneira autônoma no Estatuto."27

Maria Sylvia Zanella Di Pietro, depois de comentar que a prática de crimes que não geram a demissão permite que o servidor continue a receber parte dos vencimentos durante o período de cumprimento de pena criminal, aduz: "O ilícito penal, só por si, não enseja punição disciplinar." ${ }^{8}$

Grife-se: um servidor público não pode ser demitido pelo fato de cometer um crime previsto no Código Penal, se o crime não é definido de forma autônoma como infração disciplinar no estatuto do funcionalismo, visto que, por força do princípio da legalidade, não podem ser aplicadas punições não previstas em lei (sobretudo no caso de penalidades disciplinares gravíssimas, como é o caso da sanção demissória) pela incursão em conduta que não seja expressamente tipificada no regime disciplinar legal dos servidores públicos dentre as causas taxativas de penalidade de expulsão do serviço público, como são expressamente previstos os crimes contra a Administração Pública, inclusive a corrupção e o abandono de cargo, ou no caso de crime comum de usura, tipificado na legislação penal (art. 4, "a" e "b", da lei n. $1.521 / 51$ ) e na Lei $n^{\circ} 8.112 / 90$ (art. 117, XIV, c.c. art. 132, XIII).

\section{Descabimento da contagem dos prazos prescricionais da lei penal para punição de infrações estritamente disciplinares}

Por outro lado, os prazos da lei penal não podem ser estendidos, para fins de cômputo do prazo prescricional de punição das faltas administrativas puras. Se o servidor cometeu insubordinação grave em serviço (falta exclusivamente disciplinar) e peculato (crime que é também tipificado como falta disciplinar passível de demissão), os prazos prescricionais fixados no Código Penal somente incidirão quanto à apenação da prática de crime contra a Administração Pública de peculato, sendo de cinco anos o tempo máximo para demissão pela insubordinação grave.

Nesse sentido, o Superior Tribunal de Justiça destacou que o prazo prescricional para punição de falta funcional criminosa de concussão é o da lei penal (que também é capitulada de forma autônoma, na Lei no 8.112/90, como causa de demissão, enquanto crime contra a Administração Pública: art. 132, I), mas a falta

${ }^{27}$ CRETELLA JÚNIOR. Prática de processo administrativo, p. 124.

${ }^{28}$ DI PIETRO. Direito administrativo, p. 527.

A \& C R. de Dir. Administrativo e Constitucional, Belo Horizonte, ano 6, n. 26, p. 161-198, out./dez. 2006 
exclusivamente disciplinar também cometida pelo acusado, prevista no art. 117, IX, da Lei $n^{\circ} 8.112 / 90$ ("valer-se do cargo para lograr proveito pessoal ou de outrem, em detrimento da dignidade da função pública"), se sujeita ao prazo extintivo de cinco anos, capitulado para as infrações administrativas passíveis de demissão (art. 142, I, Lei $n^{\circ}$ 8.112/90), e não aos ditames do Código Penal. ${ }^{29}$

Ainda sedimentou o Superior Tribunal de Justiça:

A falta administrativa, quando também prevista na lei penal como crime, prescreverá juntamente, no mesmo prazo, tanto para o Direito Disciplinar quanto para o Direito Penal (...) Entretanto admitindo a existência de falta administrativa residual (Sum. n. 18-STF), na espécie a do art. 117, IX, da Lei n. 8.112/90, deve a prescrição regular-se pelo art. 142 desse diploma legal, que prevê o prazo de cinco anos, contados a partir da ocorrência do fato, em face da extrema gravidade da pena de demissão. ${ }^{30}$

Em conseqüência, apesar de a Administração Pública poder punir as faltas exclusivamente disciplinares cometidas por servidor público, como é o caso de improbidade administrativa (art. 132, IV, Lei n ${ }^{\circ}$ 8.112/90) e se valer do cargo para lograr proveito em detrimento da dignidade da função pública (art. 117, IX, c.c. art. 132, XIII, Lei n ${ }^{\circ}$ 8.112/90), elas são consideradas faltas residuais, autônomas, diante de crimes comuns, não capitulados autonomamente como causa de demissão no estatuto disciplinar do funcionalismo, de maneira que o prazo prescricional a ser considerado, para fins de contagem da prescrição do direito de punir o servidor público na esfera administrativa, será o do estatuto disciplinar - no caso da Lei no 8.112/90: 5 anos (art. 142, I), tendo em vista que as faltas disciplinares que não são tipificadas especificamente como crimes na lei penal devem ser apenadas nos prazos legais do regime disciplinar do funcionalismo, não incidindo, em absoluto aqueles do Código Penal.

Portanto, indevida a invocação do prazo previsto na lei penal para punição de faltas exclusivamente administrativas. No que concerne à prática de crimes comuns, portanto, se não previstos no estatuto disciplinar como causa de demissão, não podem ser motivo de direito para aplicar a penalidade demissória, por reflexo do princípio da legalidade e do fato de que a pena expulsória do serviço público depende de motivos vinculados e, por óbvio, da previsão em lei da conduta

\footnotetext{
29 BRASIL. Superior Tribunal de Justiça. MS 8560/DF. Relatora: Min. Laurita Vaz. $3^{a}$ seção. Brasília, DF, 12 maio 2004. DJ, Brasília, DF, 01 jul. 2004, p. 170.

${ }^{30}$ BRASIL. Superior Tribunal de Justiça. MS 6.877/DF. Relator: Min. Fernando Gonçalves, julgado em 25 abr. 2001.
} 
punida (no caso da Lei $\mathrm{n}^{\circ} 8.112 / 90$, no seu art. 132), pressuposto para se falar em responsabilidade administrativa. Do contrário, estar-se-ia admitindo que a Administração Pública usurpasse a prerrogativa do Poder Judiciário em impor a responsabilidade penal aos servidores públicos criminosos, na via do processo-crime.

\section{Desclassificação dos crimes comuns para faltas exclusivamente disciplinares como meio de viabilizar a punição administrativa, mas segundo os prazos ordinários do estatuto do funcionalismo}

Insista-se. Se o delito cometido, previsto no Código Penal ou lei criminal especial, não é especificamente tipificado na lei administrativa, então se cuida de crime comum, o qual, para ser causa de punição disciplinar e para gerar a contagem prescricional respectiva pelos prazos da legislação criminal, dependeria de ser arrolado dentre as causas de demissão catalogadas no estatuto administrativo.

Por exemplo, o servidor que incorrer em prática de estupro de colega de trabalho na repartição, poderá ser demitido pelo enquadramento do fato como conduta escandalosa na repartição ou ofensa física em serviço, tipos disciplinares puros, mas o prazo para punição da falta será de cinco anos para demissão, e não os do Código Penal, na medida em que o delito criminal de estupro não é previsto, expressamente, como causa de demissão na Lei $\mathrm{n}^{\circ} 8.112 / 90$. Pode-se enquadrar a conduta (crime comum), outrossim, como improbidade administrativa, só que o prazo para punição do comportamento será o do art. 142, I, da Lei no 8.112/90: cinco anos. O motivo de direito da penalidade demissória deverá ser um fato dentre os arrolados no art. 132, da Lei ${ }^{\circ} 8.112 / 90$, sob pena de ilegalidade.

A demissão pela prática de crimes comuns (aqueles não previstos, de forma autônoma, no estatuto dos servidores públicos federais como infração disciplinar) afigura-se ilegal se invocado o fato criminal como exclusivo motivo determinante da pena administrativa, assim como será descabido, no caso, contar o prazo prescricional pelos parâmetros temporais da legislação criminal, que são impertinentes no caso de crimes comuns não tipificados autonomamente no estatuto disciplinar do funcionalismo.

Ora, o dispositivo do art. 142, $\S 2^{\circ}$, da Lei $\mathrm{n}^{\circ} 8.112 / 90$, trata do prazo para a Administração Pública punir crimes comuns, expressamente classificados como faltas disciplinares, por assim estarem definidos, de forma autônoma, na lei administrativa, hipótese em que serão considerados os marcos cronológicos da lei penal para o exercício do poder A \& C R. de Dir. Administrativo e Constitucional, Belo Horizonte, ano 6, n. 26, p. 161-198, out./dez. 2006 
disciplinar administrativo.

\section{Interpretação restritiva do art. $142, \S^{\circ}$, da Lei $n^{\circ} 8.112 / 90$ na atual disciplina do direito positivo federal}

No caso da atual redação da Lei no 8.112/90, somente serão computados os parâmetros da legislação criminal no caso de crimes contra a Administração Pública (art. 312 a 326, Código Penal, e outros delitos assim classificados em leis especiais), por serem os únicos tipificados como faltas disciplinares no diploma legislativo dos servidores da União. Nada obsta, todavia, que outros crimes, comuns, possam ser tipificados, no estatuto, como faltas disciplinares determinantes da perda do cargo público mediante demissão.

No caso de crimes comuns, que não são tipificados, de forma autônoma, no estatuto do funcionalismo, especificamente como infrações disciplinares passíveis de demissão ou outra penalidade administrativa, se não houver o enquadramento da conduta em outra falta estritamente disciplinar (improbidade administrativa, etc. - caso em que o prazo prescricional será os do art. 142, I a III, da Lei n ${ }^{\circ}$ 8.112/90, não os do Código Penal), não cabe a punição demissória, sob pena de a Administração Pública impor pena por fato não previsto em lei.

Calha a advertência de Hely Lopes Meirelles: "O que a Administração não pode é aplicar punições arbitrárias, isto é, que não estejam legalmente previstas." 31

Palhares Moreira Reis escreve que as faltas disciplinares devem estar previstas na lei, juntamente com as sanções cabíveis, sob pena de não poderem ser aplicadas, porquanto o doutrinador leciona que a Lei $\mathrm{n}^{\mathrm{O}}$ 8.112/1990 exige a tipicidade das faltas mais graves, passíveis de demissão, relacionando-as, de forma taxativa, no art. 132, únicas hipóteses em que o autor admite seja imposta a pena demissória: "Como se trata, agora, de pena mais grave, entendeu o legislador ser pudente e elencar as hipóteses em que a penalidade expulsiva da demissão pode ser aplicada." 32

No mesmo sentido é a cátedra do administrativista Edmir Netto de Araújo, o qual também pondera que, quanto aos crimes comuns, se não descritos de forma autônoma como falta disciplinar na lei administrativa, não poderão render ensejo a punições disciplinares nem a contagem de prazo prescricional pelos parâmetros temporais da lei penal, visto que não passarão de ilícitos exclusivamente penais, a serem apurados e pro-

${ }^{31}$ MEIRELLES. Direito administrativo brasileiro, p. 474. 
cessados pelo Juízo criminal competente, ressalvando a possibilidade de a autoridade administrativa enquadrar o fato em algum dispositivo que veicula infrações administrativas puras, hipótese em que os prazos prescricionais serão os ordinários do estatuto, não os da lei penal. ${ }^{33}$

\section{Estatutos estaduais e municipais que capitulam crimes comuns como infrações disciplinares}

Por essa causa que os estatutos disciplinares dos servidores do Estado de São Paulo e do Município de São Paulo, por exemplo, capitulam em seu bojo, como faltas sujeitas à pena de demissão, a prática de crimes comuns, como a tortura, o estupro, o atentado violento ao pudor, o cometimento de crime hediondo, tráfico de entorpecentes, terrorismo, causar epidemia com resultado morte, dentre outros, conforme anota Edmir Netto de Araújo, ex vi do princípio da legalidade, haja vista que os crimes comuns passam à condição de ilícitos administrativos e causas de demissão, aí sim legitimando a contagem dos prazos prescricionais pela lei penal para a punição dos crimes tipificados, de forma autônoma, no estatuto do funcionalismo, como infrações disciplinares. ${ }^{34}$

O Estatuto dos Servidores do Município de São Paulo (Lei Municipal Paulista $\mathrm{n}^{\mathrm{o}}$ 8.989, de 29.10.1979) capitula que "será aplicada a pena de demissão a bem do serviço público ao funcionário que praticar crime contra a boa ordem e a administração pública, a fé pública e a Fazenda Municipal, ou crime previsto nas leis relativas a Segurança e à Defesa Nacional" (art. 189, II). A disposição é idêntica à capitulada no Estatuto dos Servidores do Estado de São Paulo (Lei Estadual Paulista $n^{\circ} 10.261$, de 28.10.1968). A Lei Complementar Estadual Paulista no 207, de 05.01.1979 (Lei Orgânica da Polícia do Estado de São Paulo), preceitua, outrossim, que "será aplicada a pena de demissão a bem do serviço público, nos casos de praticar ato definido como crime contra a Administração Pública, a Fé Pública e a Fazenda Pública ou previsto na Lei de Segurança Nacional” (art. 75, II).

Vê-se, pois, que os estatutos procuram capitular como infrações disciplinares, passíveis de demissão, a prática de crimes comuns contra a Fé Pública, a Fazenda Pública ou a Segurança Nacional, além daqueles contra

\footnotetext{
32 REIS. Processo disciplinar, p. 273, 286.

33 ARAÚJO. Curso de direito administrativo, p. 909.

${ }^{34}$ ARAÚJO. Curso de direito administrativo, p. 914-916.
} 
a Administração Pública (312 a 326, Código Penal, e legislação extravagante). Se se interpretar que seria possível a demissão por todo e qualquer crime comum, então, chega-se à conclusão de que os estatutos dos servidores públicos em geral, inclusive a Lei no 8.112/90 (art. 132, I) conteriam uma série de dispositivos inúteis, o que, evidentemente, não procede, sobretudo à vista da magnanimidade do princípio da legalidade no direito administrativo, com o efeito prenunciado pelos diplomas legais de autorizar a Administração a aplicar penalidades disciplinares em caso de cometimento de infrações criminais comuns.

Edmir Netto de Araújo é explícito a respeito:

O Estado e o Município de São Paulo tratam de forma imprecisa o assunto, catalogando (art. 257, II, do Estatuto estadual; 189, II, do Municipal) os crimes "contra a boa ordem e a administração pública, a fé pública e a Fazenda Estadual (ou Municipal), ou previstos nas leis relativas a segurança e à defesa nacional, ampliando ainda mais o campo de incidência”. No Estado de São Paulo, ainda, a Lei Complementar no 207, de 5 de janeiro de 1979 (Lei Orgânica da polícia), em seu art. 75, II, alarga ainda mais o campo de abrangência, pois pune com demissão a prática de ato definido como crime nas normas penais citadas, eliminando a necessidade de decisão jurisdicional que considere crime o ato praticado para a responsabilização, equiparando a situação a dos comportamentos criminosos descritos autonomamente nos Estatutos. Com essas considerações, seriam enquadrados qualquer crime de falso (arts. 289 a 311 do CP), qualquer tipo de crime fiscal ou crime contra as finanças públicas, e os que atentam contra a segurança e a defesa nacional. (...) Na prática, então, quanto aos crimes comuns, é indispensável que a Comissão Processante e a autoridade julgadora procedam ao estudo criterioso de cada caso concreto para o devido enquadramento, inclusive aguardando-se, se for o caso, a decisão judicial: se não for descrita autonomamente a conduta na lei administrativa, remete-se a questão para o Juizo criminal, único competente para declarar a ocorrência de delito e seu autor, sendo aqui integral a comunicabilidade da sentença penal. ${ }^{35}$

Daí que Edmir Netto de Araújo, conquanto admita não ser obrigatório sobrestar o julgamento do processo administrativo disciplinar para que a Administração Pública demita servidor pela prática de crime contra a Administração Pública (porque expressamente catalogado como infração sujeita a demissão no art. 132, I, da Lei $\mathrm{n}^{\mathrm{o}}$ 8.112/90), entende, porém, que descabe a punição por crime comum se a conduta não é tipificada, de forma autônoma, no estatuto do funcionalismo, como causa de pena demissória.

O crime contra a Administração Pública, segundo o entendimento do Supremo Tribunal Federal, para fins administrativos, é infração disciplinar, se tipificado na lei administrativa como causa de demissão, juízo compartilhado por Marcelo Caetano: "O crime contra a Administração Pública é conA \& C R. de Dir. Administrativo e Constitucional, Belo Horizonte, ano 6, n. 26, p. 161-198, out./dez. 2006 
siderado especificamente na lei administrativa como infração disciplinar". ${ }^{36}$ José Armando da Costa ajunta:

A prática de delito contra a Administração Pública pelo funcionário constitui ilícito disciplinar ensejador da pena disciplinar capital (demissão). O justo título gerador da reprimenda demissória é, nesses casos, a prática de crime contra a administração. ${ }^{37}$

Destarte, se o crime contra a Administração Pública é punido porque constitui infração disciplinar, assim tipificado na Lei $n^{\circ}$ 8.112/90, segue que os crimes comuns não previstos como falta funcional do estatuto dos servidores públicos não podem motivar apenação administrativa, sob pena de agressão à legalidade dos atos administrativos, sobretudo os sancionadores, a não ser que se admita que o Estado pode exercer seu poder de punir de forma livre e irrestrita, independentemente de previsão legal, o que não se conforma ao disposto no caput do art. 37 da Constituição Federal de 1988.

Nesse particular, calha a advertência do professor Romeu Felipe Bacellar Filho:

A Administração não pode agir quando a lei não autorize expressamente, não podendo incidir sobre a esfera jurídica do indivíduo sem a previsão legal. ${ }^{38}$

Por corolário, se o ilícito é previsto exclusivamente no campo penal, não tipificado expressamente, de forma autônoma, como falta disciplinar, no estatuto administrativo dos servidores públicos, cuida-se de ilícito puramente criminal, cuja correspondente apuração e punição somente podem ser ultimados pela autoridade judiciária competente, não pela autoridade administrativa, a qual somente pode aplicar penalidades previstas em lei, maiormente em caso de condutas passíveis de demissão, cujos motivos fáticos são elementos vinculados.

Se a Administração Pública considerasse que o servidor deveria ser demitido, única e exclusivamente, por cometer crime de falsidade ideológica, estupro, atentado violento ao pudor, prática de crime hediondo, injúria, difamação, violação de sepultura, ocultação de cadáver, etc., deveria ter incluído previsão expressa de demissão nesse caso, ocasião

\footnotetext{
${ }^{35}$ ARAÚJO. Curso de direito administrativo, p. 843.

${ }^{36}$ CAETANO. Princípios fundamentais do direito administrativo, p. 391.

${ }^{37}$ COSTA. Direito administrativo disciplinar, p. 510.

${ }^{38}$ BACELLAR FILHO. Princípios constitucionais do processo administrativo disciplinar, p. 162.
} 
em que, aí sim, seria caso de computar o prazo prescricional da lei penal para contagem da prescrição na esfera administrativa, como se dá nos casos de crimes contra a Administração Pública, previstos como causa de imposição de penalidade demissória aos servidores públicos federais (art. 132, I, Lei n ${ }^{\circ} 8.112 / 90$ ), de abandono de cargo (art. 138, Lei $n^{\text {o }}$ 8.112/90 e art. 323, Código Penal). Consigne-se que não quer dizer que esses fatos não possam ser reenquadrados como infrações disciplinares (como conduta escandalosa na repartição, ofensa física em serviço, etc.), mas os marcos cronológicos, no caso, serão os da lei penal.

Não se confunda, outrossim, o efeito acessório de sentença penal condenatória, quando aplicada pena privativa de liberdade por tempo igual ou superior a um ano, nos crimes praticados com abuso de poder ou violação de dever para com a Administração Pública, ou quando for aplicada pena privativa de liberdade por tempo superior a 4 (quatro) anos, nos demais casos (art. 92, I, "a" e "b”, Código Penal, com a redação determinada pela Lei n $\left.{ }^{\circ} 9.268 / 1996\right)$, hipótese em que a perda do cargo decorre da pena criminal, e não de uma sanção administrativa, nem de processo disciplinar.

Mas reitere-se: se não existe previsão no estatuto disciplinar do crime como infração disciplinar tipificada em caráter autônomo, não se pode aplicar demissão nem considerar o prazo da lei penal para computar a prescrição do direito de punir as infrações disciplinares. Calha a lição de Eduardo Pinto Pessoa Sobrinho: "A prescrição da pena decorre da natureza da falta, conforme previsto em lei, e não de eventual vinculação com outras irregularidades." 39

\section{Auxílio-reclusão e prática de crime comum cuja sentença penal condenatória respectiva não determina a perda do cargo público}

Tanto é verdade que a prática de crime comum (não tipificado de forma autônoma na Lei $n^{\circ}$ 8.112/90 como causa de demissão) impede a imposição de pena disciplinar (pelo menos a punição pela prática do crime e pelos prazos da lei penal, admitindo-se, porém, o reenquadramento para ilícito disciplinar puro) que o próprio estatuto dos servidores públicos federais capitula que, durante o cumprimento de pena criminal por crime comum, a família do servidor preso receberá auxílio-reclusão (art. 229, Lei no 8.112/90). ${ }^{40}$

Ivan Barbosa Rigolin confirma que, de fato, a Administração Pública não pode demitir servidor público por crime comum ou hediondo 
não tipificado como falta disciplinar passível de punições administrativas, modo por que o administrativista propõe que a Administração Pública demita o servidor que cumpre pena por delitos penais dessa natureza por inassiduidade habitual (solução que não se endossa, mas que prova a impossibilidade de demissão em caso de crime comum não tipificado, de forma autônoma, como infração disciplinar): "À falta de melhor enquadramento na Lei $\mathrm{n}^{\mathrm{o}} 8.112$, deve-se indiciar em processo administrativo por inassiduidade habitual o servidor público condenado por crime comum ou hediondo, cumprindo pena, para o fim de, ao término do mesmo processo, demiti-lo do serviço público." ${ }^{41}$

Destaque-se, no entanto, data venia, que não se pode punir por inassiduidade habitual ou abandono de cargo o servidor que é condenado pela prática de crime comum cuja pena não seja acompanhada de sanção acessória da perda do cargo, mesmo porque o estatuto prevê o benefício previdenciário do auxílio-reclusão, o qual é incompatível com a punição disciplinar pelo mesmo fato amparado na disciplina da Lei $\mathrm{n}^{\circ}$ 8.112/90, além de o servidor estar submetido a circunstância de força maior (privação de liberdade em função de sentença penal condenatória em execução), que exclui a voluntariedade no cometimento de infrações disciplinares de abandono de cargo (“animus abandonandi” inexistente) ou inassiduidade habitual.

O correto será o pagamento de auxílio-reclusão, se a condenação criminal não implicou a perda do cargo público.

\section{Pressupostos complementares para contagem dos prazos pres- cricionais da lei penal para punição administrativa na jurisprudência do Superior Tribunal de Justiça}

O Superior Tribunal de Justiça estatuiu:

Não havendo crime, seja porque não denunciado um dos recorrentes, sendo o

\footnotetext{
39 PESSOA SOBRINHO. Manual dos servidores do Estado, p. 1103.

${ }^{40}$ Art. 229. À família do servidor ativo é devido o auxílio-reclusão, nos seguintes valores:

I - dois terços da remuneração, quando afastado por motivo de prisão, em flagrante ou preventiva, determinada pela autoridade competente, enquanto perdurar a prisão;

II - metade da remuneração, durante o afastamento, em virtude de condenação, por sentença definitiva, a pena que não determine a perda de cargo.

$\S 1^{\circ}$ Nos casos previstos no inciso I deste artigo, o servidor terá direito à integralização da remuneração, desde que absolvido.

$\S 2^{\circ} \mathrm{O}$ pagamento do auxílio-reclusão cessará a partir do dia imediato àquele em que o servidor for posto em liberdade, ainda que condicional.

${ }^{41}$ RIGOLIN. Comentários ao regime único dos servidores públicos civis, p. 245.
} 
outro impronunciado por falta de provas, ausente o parâmetro da lei penal a regular o prazo extintivo da ação estatal, sendo, pois, a sanção de caráter administrativo. Regula, então, a prescrição, neste caso, a legislação relativa ao processo administrativo disciplinar. ${ }^{42}$

Mas o STJ firmou que não incidem os parâmetros de contagem do prazo prescricional capitulados na lei penal, mas antes as regras administrativas do estatuto disciplinar do funcionalismo, no concernente à prescrição do direito de punir faltas exclusivamente funcionais, se apenas existem indícios de crime, nem sequer apurado, à míngua da formulação de denúncia ao juízo penal competente:

A mera presença de indícios de prática de crime sem a devida apuração nem formulação de denúncia, obsta a aplicação do regramento da legislação penal para fins de prescrição, devendo esta ser regulada pela norma administrativa, ${ }^{43}$ mesmo em caso de apuração dos fatos em processo criminal efetivamente instaurado, no qual, todavia, os acusados foram absolvidos, ante a ausência de provas suficientes para a eventual condenação. ${ }^{44}$

\section{Acusação da prática de crime como artifício para permitir a punição do servidor público após já estar prescrita a pretensão punitiva da Administração Pública segundo os prazos ordinários do estatuto dos servidores: precedentes do Supremo Tribunal Federal}

Conduta imoral da Administração Pública é a de manejar uma acusação de prática de crime contra o servidor acusado, nunca anteriormente formalizada ao longo de anos de tramitação do processo administrativo disciplinar, como meio de driblar a já consumada prescrição do direito de punir estatal.

Sucede, ainda, lamentavelmente, de órgãos administrativos jurídicos, de forma imoral, ao perceberem que já se verificou o decurso do prazo prescricional da pretensão punitiva da falta disciplinar cometida, conforme os limites temporais impostos no estatuto dos servidores, resolverem articular uma imputação da suposto cometimento de ilícito penal pelo funcionário increpado como meio de invocar, artificiosamente, os marcos cronológicos mais extensos da legislação criminal para punição de

\footnotetext{
42 BRASIL. Superior Tribunal de Justiça. ROMS 10699/RS. Órgão julgador: $6^{a}$ turma. Brasília, DF. Relator: Min. Fernando Gonçalves. Decisão. Brasília, DF, 03 dez. 2001. DJ, Brasília, DF, p. 544, 04 fev. 2002.

${ }^{43}$ BRASIL. Superior Tribunal de Justiça. ROMS 14420/RS. Órgão julgador: $6^{a}$ turma. Relator: Min. Vicente Leal. Brasília, DF, 15 ago. 2002. DJ, Brasília, DF, p. 291, 30 set. 2002.

${ }^{44}$ BRASIL. Superior Tribunal de Justiça. ROMS 13542/SP. Órgão julgador: $5^{a}$ turma. Relator: Min. Gilson Dipp. Brasília, DF, 12 ago. 2003. DJ, Brasília, DF, p. 343, 22 set. 2003.
} 
faltas na verdade estritamente disciplinares.

Pior, os órgãos de consultoria ainda incorrem em intolerável cerceamento de defesa por meio do oferecimento da acusação de prática de ilícito penal sem propiciar, previamente ao julgamento, oportunidade para o acusado ou seu defensor refutarem a nova imputação, jamais deduzida ao longo de 8 ou 10 anos de tramitação do processo disciplinar.

A esse respeito, o Supremo Tribunal Federal proferiu ilustrativo julgado. ${ }^{45}$ Cuidava-se de situação concreta em que servidor público federal, investigado pela suposta prática de crimes contra a Administração Pública de prevaricação e corrupção passiva, teve arquivado o inquérito policial em que era indiciado, uma vez que o Procurador da República, considerando inexistente o cometimento dos ilícitos penais por parte do agente público, deixou de ofertar denúncia, medida ratificada pelo senhor Procurador-Geral da República, após a discordância da juíza federal competente quanto à não-propositura da ação penal pública.

Depois de decorridos mais de oito anos de tramitação do processo administrativo disciplinar, vendo que já expirara o prazo prescricional de quatro anos para cassar a aposentadoria do acusado, a Administração Pública da União, porém, por meio de parecer da Consultoria-Geral da República, no afã de viabilizar a punição do acusado após expirado o tempo máximo para apenação administrativa, apreciando os mesmos fatos apurados no inquérito policial, valeu-se da estratégia de afirmar que o servidor teria, sim, ao contrário do que apontado pelo membro em $1^{\circ}$ grau e pelo Chefe do Ministério Público Federal, incorrido em crimes de prevaricação e corrupção passiva, o que ensejaria a contagem dos prazos prescricionais do Código Penal (16 anos para corrupção passiva) para punir o servidor no âmbito administrativo, motivo por que o Presidente da República cassou a aposentadoria do acusado.

O Supremo Tribunal Federal decidiu que o prazo prescricional para punição de infrações disciplinares, na espécie, deveria ser o estipulado ordinariamente no Estatuto dos Servidores Públicos federais, de quatro anos, e não os do Código Penal, em caso de arquivamento do inquérito policial, se idênticos os fatos apurados no inquérito policial e no processo administrativo disciplinar.

Merece transcrição trecho do erudito voto do nobre Ministro Oscar Corrêa, relator da matéria na Corte Suprema:

\footnotetext{
${ }^{45}$ BRASIL. Supremo Tribunal Federal. Mandado de Segurança $n^{\circ}$ 20.645. Tribunal Pleno. Relator: Min. Oscar Corrêa. Brasília, DF, 30 abr. 1987. Publicado na Revista de Direito Administrativo, v. 168, p. 92-122, abr./ jun. 1987.
}

A \& C R. de Dir. Administrativo e Constitucional, Belo Horizonte, ano 6, n. 26, p. 161-198, out./dez. 2006 
Nossa argumentação pode ser singelamente resumida: I - o processo disciplinar - que concluiu com a cassação de aposentadoria - excedeu o prazo prescricional do art. 213 da Lei $\mathrm{n}^{\circ} 1.711 / 52$, II, b, que é de quatro anos. E que é também o do art. 390, II, do Decreto ${ }^{\circ} 59.310 / 66$. II - Não se aplica à hipótese o parágrafo único do mesmo art. 213, que estipula que "a falta também prevista na lei penal como crime prescreve juntamente com este”, porque: a) não acolhida a materialidade dos delitos, requerido o arquivamento dos inquéritos - quer por prevaricação, quer pela corrupção passiva; b) arquivados os inquéritos, a reabertura só se poderia dar com o surgimento de novas provas (Súmula $n^{\circ} 524$ ); e o que houve foi apenas a enunciação de novo parecer, e não o aparecimento de novas provas e se o arquivamento não faz coisa julgada material, a emissão de novo parecer não se equipara, nem assemelha, ao surgimento de novas provas, que autorizassem a reabertura. (...) A segunda - de fundo - é que o parecer limita-se a argumentar em torno dos mesmos fatos que, julgados insuficientes para tipificar os delitos, quer de prevaricação, quer de corrupção passiva, determinaram os pedidos de arquivamento. Não é caso de rediscutir, por despiciendo, a natureza desse pedido, nem foi ela posta em dúvida. O que se afirma - e não o ignorou o parecerista ilustre - é que novas provas não se aduziram, limitando-se a carrear para o seu pronunciamento os elementos do processo disciplinar, para reanalisá-lo e o diz (fl. 47).

Ora, viola gravemente o seu dever de boa-fé e segurança jurídica (no sentido de confiabilidade e previsão do comportamento da Administração Pública perante o administrado no processo administrativo) o manejo pelo Estado do expediente de articular, de forma extemporânea, como mero subterfúgio para driblar a prescrição já consumada segundo os prazos ordinários do estatuto dos servidores públicos, acusação de prática de crime como meio de fazer incidir, artificiosamente, a contagem dos prazos prescricionais da lei penal (de regra mais longos) para viabilizar uma punição disciplinar que não mais tinha cabimento cronologicamente.

O Ministro Oscar Corrêa, nesse particular, critica a tentativa da Administração Pública de contornar a prescrição pelo expediente de reapreciar os mesmos fatos sobre os quais já se tinha requerido o arquivamento do inquérito policial por meio de parecer da Consultoria-Geral da República, que foi invocado como motivo para cassar a aposentadoria do servidor, pior ainda porque o acusado nem sequer foi intimado a se pronunciar sobre a nova acusação:

Mais, o mais importante, é que cassada a aposentadoria por corrupção passiva - uma única vez se refere o fundamento penal da cassação; e sem se dar ao trabalho sequer de nominá-la, ou indicar o texto legal que a prevê, nem os fundamentos para a adoção do tipo. E sem indagar sequer se se consumou o 
recebimento da propina, entregue ao escrivão descriminado. E sem que se tenha tomado qualquer medida de persecução penal. Em síntese: sem demonstrar qualquer das ações do tipo objetivo: solicitar, receber ou aceitar - que o parecer não explicita, em absoluto. E sem que sobre ela, ao que se saiba, se tenha pronunciado o impetrante, defendendo-se. Em afã incriminatório que transparece evidente em todas as palavras, em contraste com a benignidade para com os outros indiciados: o "in dúbio pro reo" vale para estes, não para aquele. Assim, sem demonstrar a ocorrência da corrupção passiva - a que apenas alude, uma vez - propõe a cassação da aposentadoria do impetrante. E não se instaura ação penal, não se convoca o acusado, não se busca tipificar o crime; apenas se atinge uma finalidade: a cassação de aposentadoria, conseqüência única do parecer com base exclusiva na elaboração a que procedeu (...) Dessa maneira, arquivados os inquéritos policiais, onde se fazia acusação de prevaricação (CP, art. 319), pelas conclusões da Procuradoria-Geral da República acima transcritas, força é ter presente a ampla conexão entre os fatos, objeto do inquérito arquivado e os do Inquérito $\mathrm{n}^{\circ} 77 / 82$, acentuando-se (fls. 14): “Com efeito, se no Inquérito $\mathrm{n}^{\circ} 77 / 82$ ficar evidenciado que houve prevaricação, haverá indício de que tenha havido corrupção da autoridade que tenha prevaricado. Se ficar, porém, comprovado que não houve prevaricação, pulveriza-se também a acusação de corrupção (...) Por conseguinte, esboroa-se o último argumento em que se fundam em informações, pois, se, na esfera criminal, sequer o crime de prevaricação restou comprovado, razão muito menos haverá para dizer-se tenha o impetrante incorrido na prática do crime de corrupção passiva (...) Não há, dessa sorte, na espécie, invocar o parágrafo único do art. 213, da Lei $n^{\circ} 1.711 / 52$, pois, em realidade, não se imputou ao impetrante a autoria nem de crime de prevaricação, nem de corrupção passiva. Somente o Ministério Público federal poderia acusar o impetrante, enquanto Delegado da Polícia Federal, da prática de crime contra a Administração Pública federal." (grifo nosso)

\section{O nobre Ministro Oscar Corrêa arremata seu voto:}

Se, dessa maneira, ao ensejo do ato administrativo impugnado, de cassação de aposentadoria da impetrante, subsistia a decisão de arquivamento dos inquéritos policiais, onde assentado que não existia prova da materialidade dos crimes de prevaricação e de corrupção passiva, força é entender que a prescrição da falta disciplinar cogitada, a título de resíduo, não poderá, efetivamente, ser visualizada, à luz do art. 213, parágrafo único, da Lei $n^{\circ}$ 1.711/52, mas tão-só, na conformidade do preceito explícito do art. 213, II, letra $b$, do mesmo diploma, consoante o qual prescreverá, em quatro anos, a cassação de aposentadoria ou disponibilidade. (grifo nosso)

\section{O eminente ministro Moreira Alves complementa:}

Entendo que, tendo havido arquivamento das ações penais, a cassação da aposentadoria, enquanto não forem elas desarquivadas em virtude de novas provas, só poderia dar-se por outro motivo que não o da prática dos crimes objeto delas, inclusive, portanto, o de corrupção passiva. Conseqüentemente, o prazo de prescrição é o de quatro anos.

O Supremo Tribunal Federal, em outro histórico precedente, ${ }^{46}$ fincou que, se o servidor público foi acusado de prática de peculato culposo e o juiz criminal 
competente declarou a extinção da punibilidade pela prescrição, não é dado à Administração Pública demitir o funcionário, atribuindo-lhe a prática de infração penal, pelos mesmos fatos, reclassificados pela autoridade administrativa como peculato doloso, modo por que se anulou a penalidade demissória imposta:

Se o juiz criminal proclamou a inocência do funcionário, por ausência do elemento causal, ou por entender haver ele cometido determinado delito e não outro, não será lícito ao Poder Administrativo, com base no mesmo fato, modificar a classificação do delito e insistir na infração disciplinar pela qual puniu o funcionário ou pretende fazê-lo. É que, no conceito do fato, punível, constitui elemento essencial sua tipicidade, isto é, a conformidade do fato com a descrição precisa da definição legal. (grifo nosso)

\section{O Tribunal Federal de Recursos julgou:}

Arquivado o inquérito policial, por ausência de justa causa para a ação penal, visto que os fatos narrados nem mesmo em tese constituiriam crime (CPP, ART.43, I), não ha como demitir-se o funcionário se contra ele não ficaram comprovadas a materialidade nem a autoria dos fatos. A pena de demissão somente se aplica em processo administrativo disciplinar dos estáveis, se comprovadas aquelas circunstâncias. A inexistência de resíduo administrativo autorizativo de tal punição, leva ao desfazimento do ato inquinado. ${ }^{47}$

O Superior Tribunal de Justiça sublinhou que, "havendo regular apuração criminal, deve ser aplicada a legislação penal para o cômputo da prescrição no processo administrativo"; 48 "na presente hipótese, constituindo a falta praticada pelo servidor o delito de peculato tipificado no art. 312 do Código Penal, bem como tendo sido o servidor denunciado e estando a ação penal em regular trâmite, aplica-se na instância administrativa o prazo prescricional previsto na instância penal — dezesseis anos, nos moldes do art. 109, II do Código Penal." 49

O STJ ainda sedimentou:

Ao se adotar na instância administrativa o modelo do prazo prescricional vigente na instância penal, deve-se aplicar os prazos prescricionais ao processo administrativo disciplinar nos mesmos moldes que aplicados no processo criminal, vale dizer, prescreve o poder disciplinar contra o servidor com base na pena cominada em abstrato, nos prazos do artigo 109 do Código Penal, enquanto não houver sentença penal condenatória com trânsito em julgado para acusação, e, após o referido trânsito ou improvimento do recurso da acusação, com base na pena aplicada em concreto (artigo 110 , parágrafo $1^{\circ}$, combinado com o artigo 109 do Código Penal). ${ }^{50}$

\footnotetext{
${ }^{46}$ BRASIL. Supremo Tribunal Federal. Mandado de Segurança $n^{\circ}$ 19.986/DF. Tribunal Pleno. Relator: Min. Xavier de Albuquerque. Brasília, DF, 02 jun. 1976.

${ }^{47}$ Tribunal Federal de Recursos. RIP 03125157. Relator: Min. Gueiros Leite. Brasília, DF, 09 dez. 1980. AC n 55580/RJ. Órgão julgador: 2a turma. Apelação Cível. DJ, Brasília, DF, 26 fev. 1981. EJ, v. 1-3, p. 107.
} 
Deve-se averiguar se o servidor foi denunciado para fins de se justificar a contagem do prazo prescricional pelo Código Penal (art. 142, §2 Lei $\left.\mathrm{n}^{\mathrm{o}} 8.112 / 90\right)$.

Eis, pois, algumas reflexões que pareciam relevantes sobre a matéria.

\section{Conclusões}

a) no texto da vigente, Lei $\mathrm{n}^{\circ} 8.112 / 90$, somente são faltas administrativas que também constituem crimes, para os efeitos do art. 142, $\S 2^{\circ}$, do aludido diploma legal, aquelas previstas no art. 132, I, do Estatuto dos Servidores Públicos Federais, os crimes contra a Administração Pública;

b) a responsabilidade administrativa decorre da prática de ilícito tipificado no estatuto disciplinar dos servidores públicos, de maneira que somente haverá ensejo para punição funcional se o crime comum ou o ilícito exclusivamente disciplinar é previsto, na lei administrativa, como infração passível de penalidade;

c) a demissão de servidor público, no regime da Lei n ${ }^{\circ}$ 8.112/90, somente pode ser aplicada nos casos expressamente catalogados no seu art. 132, sob pena de ofensa ao princípio da legalidade, visto que o estatuto do funcionalismo federal elencou, de forma taxativa, as hipóteses em que admitida a punição expulsória;

d) os crimes somente podem ser motivo de demissão de servidor público quando o delito penal for previsto, no estatuto disciplinar do funcionalismo, de forma autônoma, como falta disciplinar, como é o caso dos crimes contra a Administração Pública (art. 132, I, Lei $\left.\mathrm{n}^{\mathrm{o}} 8.112 / 90\right)$, quando os prazos prescricionais para apenação administrativa serão os da lei penal (art. 142, §2 ${ }^{\circ}$ Lei $\left.\mathrm{n}^{\mathrm{o}} 8.112 / 90\right)$;

e) crimes comuns, não previstos expressamente como faltas disciplinares no estatuto do funcionalismo, não podem render ensejo a pena administrativa de demissão, nem permitirão que os prazos

\footnotetext{
${ }^{48}$ BRASIL. Superior Tribunal de Justiça. RMS 18688/RJ. Órgão julgador: $5^{a}$ turma. Relator: Min. Gilson Dipp. Julgamento de 07 dez. 2004. DJ, p. 206, 09 fev. 2005.

${ }^{49}$ BRASIL. Superior Tribunal de Justiça. RMS 18093/PR, 2004/0043040-8. Órgão julgador: $5^{a}$ turma. Relator: Min. Gilson Dipp. Brasília, DF, 04 nov. 2004, DJ, Brasília, DF, p. 384, 13 dez. 2004.

${ }^{50}$ BRASIL. Superior Tribunal de Justiça. RMS 13395/RS. Órgão julgador: $6^{a}$ turma. Relator: Min. Hamilton Carvalhido. Brasília, DF, 26 maio 2004, DJ, Brasília, DF, p. 569, 02 ago. 2004.
} 
prescricionais da lei penal incidam para a contagem dos limites temporais para o exercício do direito de punir da Administração Pública, o qual somente poderá ser exercitado se o fato criminoso for reenquadrado em um dos tipos de infrações disciplinares puras, quando, todavia, o prazo de exaurimento da pretensão punitiva será de cinco anos para demissão (art. 142, I, Lei $\mathrm{n}^{\circ}$ 8.112/90), e não os do Código Penal ou legislação criminal extravagante;

f) a doutrina do direito administrativo disciplinar tem encimado que as penas mais graves (demissão, cassação de aposentadoria) somente podem ser aplicadas se as condutas a elas sujeitas forem tipificadas no regime legal disciplinar dos servidores públicos, tendência consagrada no direito brasileiro desde os Estatutos de 1939 (Decreto-lei 1.713/39) e de 1952 (Lei no 1.711/52), mantida na atual Lei $n^{\circ} 8.112 / 90$;

g) a discricionariedade, no âmbito do direito administrativo disciplinar, tem sofrido expressiva restrição no que concerne à capitulação de tipos abertos de faltas funcionais, haja vista que a tendência, no ordenamento jurídico pátrio, é de definir, como causas de penas mais graves (demissão, cassação de aposentadoria e disponibilidade), fatos com tipos fechados ou de conteúdo normativo preciso ou definido com exatidão doutrinariamente, tanto que a punição demissória por infrações como "procedimento grave ou irregular", outrora existente no Estatuto dos Funcionários Públicos federais de 1939, não foi reproduzido na Lei $\mathrm{n}^{\circ} 1.711 / 52$, nem tampouco na Lei $\mathrm{n}^{\circ}$ 8.112/90;

h) a idéia de dispensa da exigibilidade da previsão legal das infrações disciplinares, mas somente das penas aplicáveis, originária do direito francês, encontra-se superada no direito positivo pátrio e em considerável parte da doutrina do direito administrativo brasileiro e estrangeiro, haja vista a exigência de previsão legal das condutas sujeitas às sanções mais graves.

i) não se pode abonar o expediente imoral e malicioso da Administração Pública de recorrer à imputação da prática de crime contra servidor acusado em processo administrativo disciplinar como subterfúgio para viabilizar a punição administrativa tardiamente, cujo prazo prescricional efetivamente aplicável, o 
ordinário do estatuto do funcionalismo, já se encontra expirado, máxime após o decurso de mais de oito, nove anos de tramitação do feito punitivo sem decisão, sob pena de agressão aos princípios constitucionais da impessoalidade, segurança jurídica e da legalidade, além do menosprezo decorrente ao dever processual de boa-fé do Estado perante os administrados.

j) a tendência jurisprudencial é de somente permitir a contagem dos prazos prescricionais, para punição disciplinar, pelos parâmetros da lei penal quando houver a tramitação de processo-crime ou o servidor for indiciado em inquérito policial, computandose os marcos temporais ordinários do estatuto do funcionalismo em caso contrário, não os da legislação criminal.

\section{Referências}

ALTAMIRA, Pedro Guillermo. Curso de derecho administrativo. Buenos Aires: Depalma, 1971.

ARAÚJO, Edmir Netto de. Curso de direito administrativo. São Paulo: Saraiva, 2005.

BACELLAR FILHO, Romeu Felipe. Princípios constitucionais do processo administrativo disciplinar. São Paulo: Max Limonad, 1998.

BANDEIRA DE MELLO, Oswaldo Aranha. Princípios gerais de direito administrativo. Rio de Janeiro: Forense, 1969. v. 2.

BARROS JÚNIOR, Carlos S. de. Do poder disciplinar na administração pública. São Paulo: Revista dos Tribunais, 1972.

BRAZ, Petrônio. Manual de direito administrativo. 2. ed. São Paulo: Direito, 2001.

CAETANO, Marcelo. Princípios fundamentais do direito administrativo. Rio de Janeiro: Forense, 1977.

CAVALCANTI, Themistocles Brandão. Tratado de direito administrativo. 4. ed. São Paulo: Freitas Bastos, 1961. v. 4.

COSTA, José Armando da. Direito administrativo disciplinar. Brasília: Brasília Jurídica, 2004.

CRETELLA JÚNIOR, José. Prática de processo administrativo. 3. ed. rev. e atual. São Paulo: Revista dos Tribunais, 1999.

DI PIETRO, Maria Sylvia Zanella. Direito administrativo. 17. ed. São Paulo: Jurídico Atlas, 2004.

GARCÍA DE ENTERRÍA, Eduardo; FERNANDES, Tomás-Ramon. Curso de direito administrativo. Tradução de Arnaldo Setti. São Paulo: Revista dos Tribunais, 1990.

GARCIA-TREVIJANO FOS, Jose Antonio. Tratado de derecho administrativo. Madrid: Revista de Derecho Privado, 1970. v. 2, t. 3. 
JUSTEN FILHO, Marçal. Curso de direito administrativo. São Paulo: Saraiva, 2005.

LIMA, Vicente Ferrar Correia. Ensaio jurídico sobre o processo ou inquérito administrativo. Brasília: DASP, 1969.

MASAGÃO, Mário. Curso de direito administrativo. 5 ed. São Paulo: Revista dos Tribunais, 1974.

MEDAUAR, Odete. Direito administrativo moderno. 5 ed. rev. e atual. São Paulo: Revista dos Tribunais, 2001.

MEIRELLES, Hely Lopes. Direito administrativo brasileiro. 29. ed. atual. São Paulo: Malheiros, 2004.

OLIVEIRA, Régis Fernandes de. Servidores públicos. São Paulo: Malheiros, 2004.

PESSOA SOBRINHO, Eduardo Pinto. Manual dos servidores do Estado. 13. ed. Rio de Janeiro: Freitas Bastos, 1985.

REIS, Palhares Moreira. Processo disciplinar. 2 ed. rev. e atual. Brasília: Consulex, 1999.

RIGOLIN, Ivan Barbosa. Comentários ao regime único dos servidores públicos civis. 4. ed. atual. e aum. São Paulo: Saraiva, 1995.

ROCHA, Carmem Lúcia Antunes. Princípios constitucionais dos servidores públicos. São Paulo: Saraiva, 1999.

SILVEIRA, Olavo Tabajara. O funcionário público. São Paulo: Revista dos Tribunais, 1964.

SIMAS, Henrique de Carvalho. Manual elementar de direito administrativo. Rio de Janeiro: Freitas Bastos, 1974.

VASCONCELOS, Justino. Súmulas de legislação aplicável à função pública. Porto Alegre: Sulina, 1952.

VERA, José Bernejo. El derecho administrativo sancionador. In: MOREIRA NETO, Diogo de Figueiredo (Coord.). Uma avaliação das tendências contemporâneas do direito administrativo: anais do seminário de Direito Administrativo Brasil-Espanha, obra em homenagem a Eduardo García de Enterría. Rio de Janeiro; São Paulo: Renovar, 2003.

Informação bibliográfica deste texto, conforme a NBR 6023:2002 da Associação Brasileira de Normas Técnicas (ABNT):

CARVALHO, Antonio Carlos Alencar. Contagem dos prazos prescricionais da lei penal para punições disciplinares de servidores públicos: uma paralela reflexão crítica sobre os conceitos de tipicidade e discricionariedade das faltas administrativas para os fins do art. $142, \S 2^{\circ}$, da Lei $n^{\circ}$ 8.112/90. A\&C Revista de Direito Administrativo e Constitucional, Belo Horizonte, ano 6, n. 26, p. 161-198, out./dez. 2006. 
